\title{
Dynamics of Goat Meat Production in Extensive Systems in Asia: Improvement of Productivity and Transformation of Livelihoods
}

\section{Devendra C}

Consulting Tropical Animal Production Systems Specialist, 130A Jalan Awan Jawa, Kuala Lumpur, Malaysia

"Corresponding author: Dr. Devendra C, PhD, DSc, Consulting Tropical Animal Production Systems Specialist, 130A Jalan Awan Jawa, 58200 Kuala Lumpur, Malaysia, Tel: 603-7987-9917; E-mail: cdev@pc.jaring.my

Rec date: Aug 22, 2014, Acc date: Nov 21, 2014, Pub date: Nov 23, 2014

Copyright: ( 2014 Devendra C. This is an open-access article distributed under the terms of the Creative Commons Attribution License, which permits unrestricted use, distribution, and reproduction in any medium, provided the original author and source are credited.

\section{Contents}

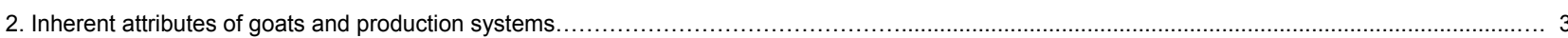

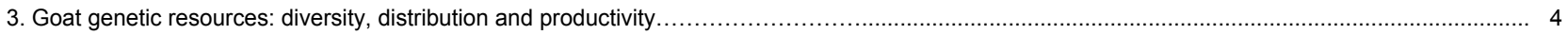

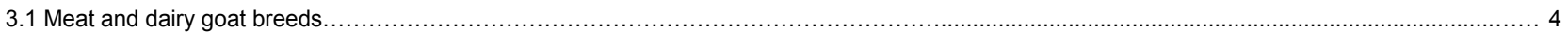

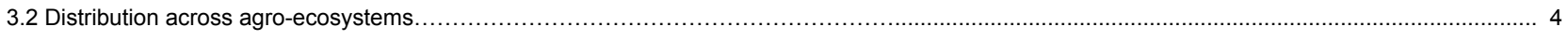

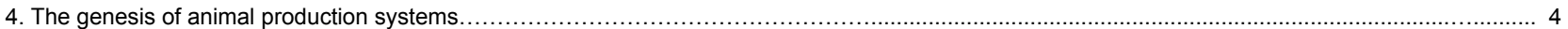

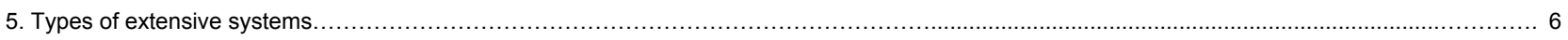

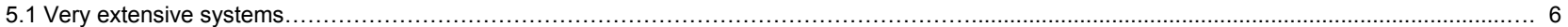

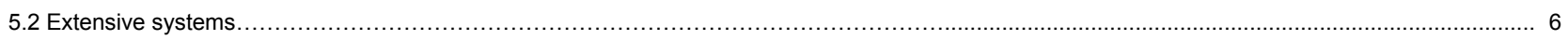

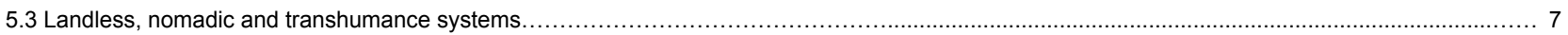

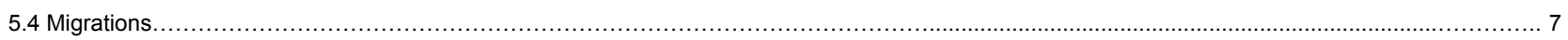

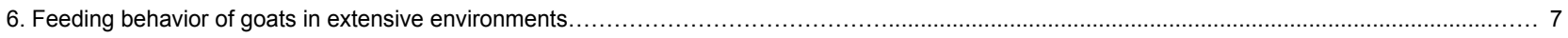

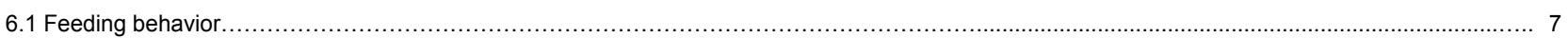

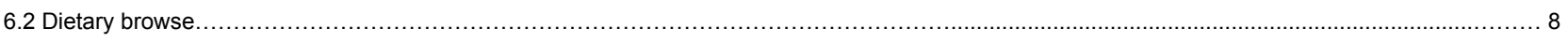

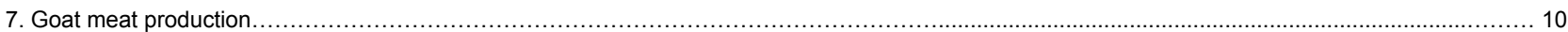

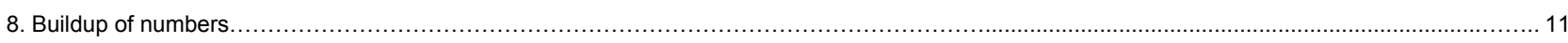

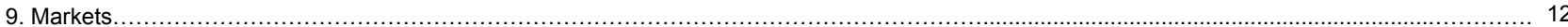

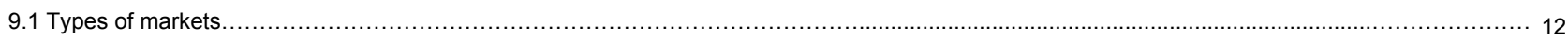

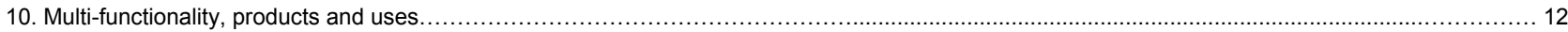

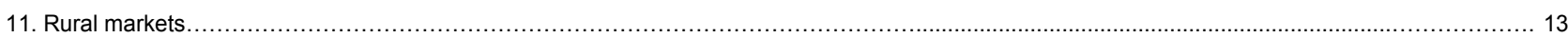

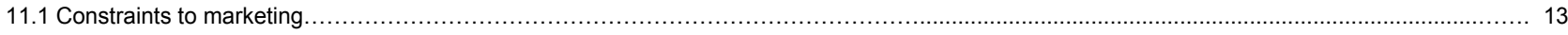

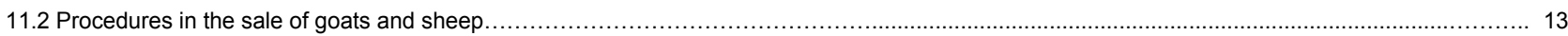

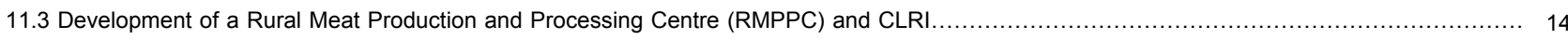

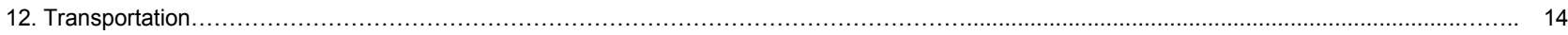

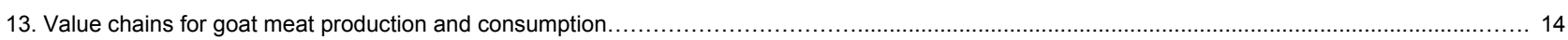

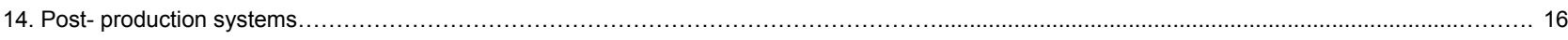

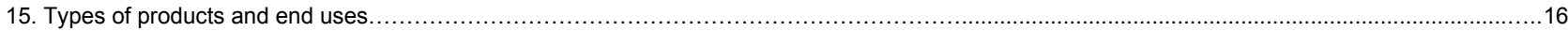




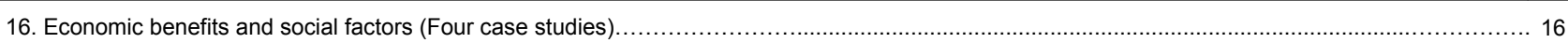

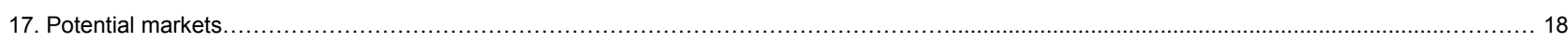

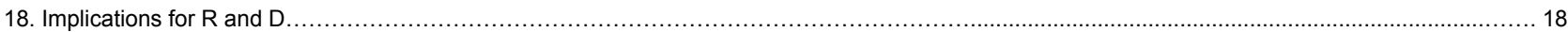

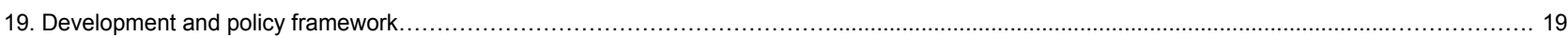

20. Conclusions

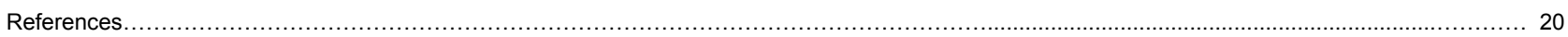

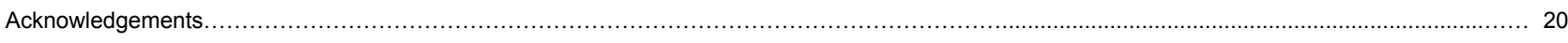

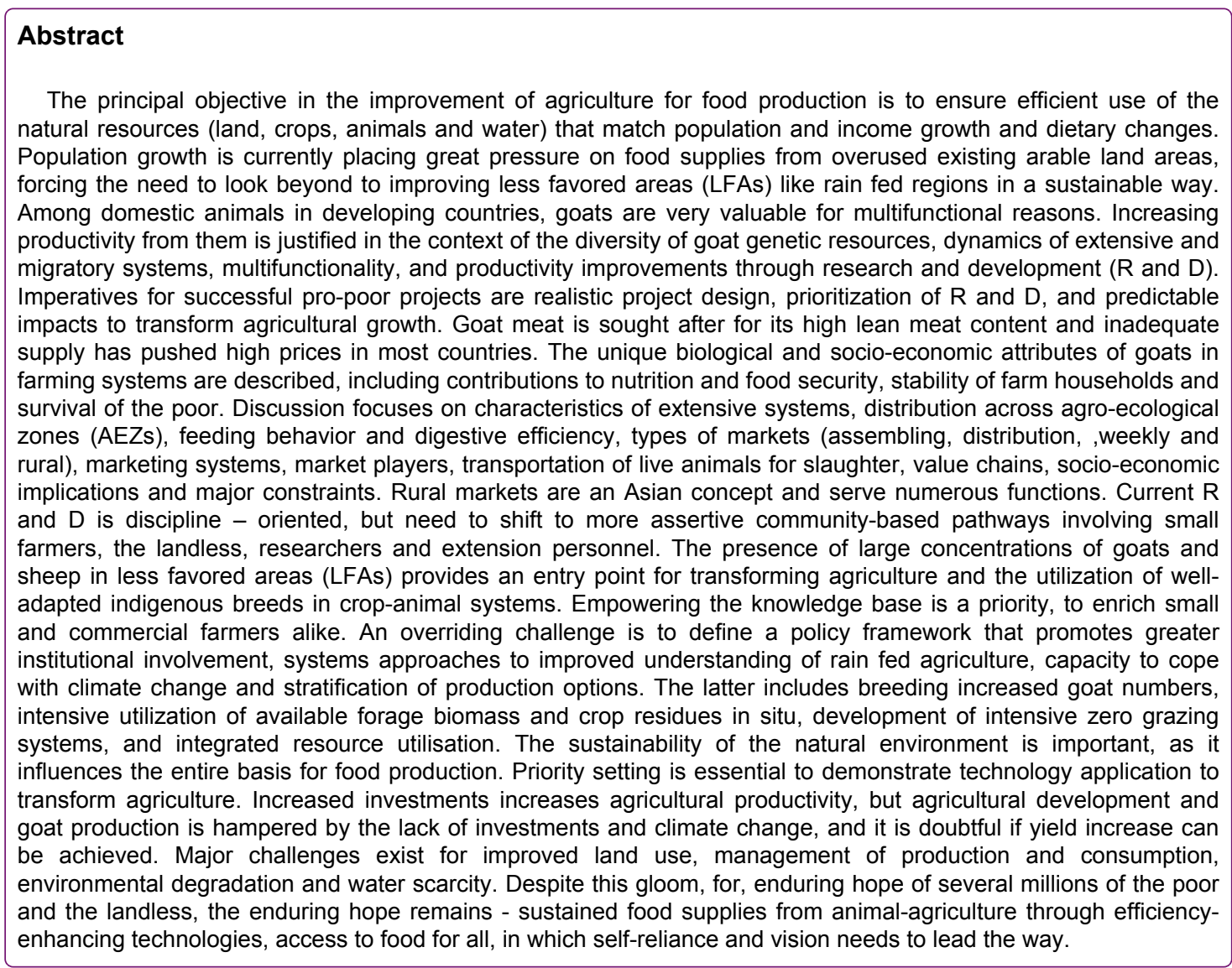

Keywords: Extensive systems; Goat meat; Types of markets; Marketing systems; Transportation; Small farmers and the landless; Market players; Value chains; Transformation; Self-reliance; Asia.

\section{Introduction}

The livestock sector which includes the main species (buffaloes, cattle, goats and sheep) is one of the fastest growing sub-sectors in agriculture. It is the second most important in the agricultural economy, superseded only by large scale staples like rice [1]. The former observation underlines the many opportunities for producers and owners of animals. Ruminants contribute directly to food and nutrition security by producing precious dietary animal proteins, and especially for the malnourished, by transforming vegetation from nonarable land, crop residues, by-products from food processing, and other non-conventional feeds for the very poor for sustaining improved livelihoods [2]. Ruminants also contribute indirectly to food security by increasing crop productivity through the return of dung and urine.

Within the available animal genetic resources, the multifunctional value of goats throughout the developing countries provide a very important social and economic niche, especially through the supply of meat and milk to enhance nutrition and food security $[3,4]$. The contributions of goats range from supplies of precious animal proteins (meat and milk) to sustain nutrition and food security; fibre and skins; providing draught power in the highlands; socio-economic stability of farm households, survival of mankind in extreme arid AEZ, and potential for providing a pathway for a brighter tomorrow. Among these, the contribution to food security is perhaps the most significant, since these borders on improvements to malnutrition and extreme poverty. The extent of the latter contributions to improved livelihoods, 
enhanced food insecurity and household stability are issues that are not inadequately understood, as a consequence of which often goat breeds do not express their full productive potential.

Milk from dairy goats for example, has several beneficial attributes, and the availability of small daily amounts averts malnutrition in children, pregnant mothers and elders. Because of its high content of mono- and poly-unsaturated fatty acids, the milk is well known to be beneficial for human health, especially for cardiovascular conditions. Due to the presence of the beneficial constituents, goat milk is sold at two to three time higher prices compared to cow milk in China, Malaysia, Indonesia and Thailand. In Indonesia, the national population of 14.9 million goats in 2011 is distributed throughout 33 provinces, with $21 \%$ in Central Java, followed by $16 \%$ in East Java, and $11 \%$ West Java. Of particular interest is the fact the goat population has an annual growth rate of about $4 \%$, and as much as $32 \%$ of the population is dairy goats [5]. For this and various other economic reasons, the expansion and wider development of dairy goats in Asia is being encouraged [6].

Since meat and milk are important products, the growth and efficiency of the production systems, orderly marketing of these products with good hygiene is essential, and is determined to a very large extent by value chains and innovation. Equally important is the capacity of the livestock keepers and producers of small ruminants in the small farms. Small farmers have major problems coping with a range of difficulties in the face of prevailing very variable, complex and inefficient marketing chains in which there is variable participation. Foremost among these is access to marketing and to the marketing chain. At present, inadequate access to market outlets, weak marketing arrangements and inadequate marketing skills represent a major constraint for small farmers, the landless and the owners and producers of dairy goats in the production to consumption systems theme. As a consequence, small farmers are often denied participation in compelling and beneficial economic opportunities and remain unprogressively.

The paper presents a comprehensive overview of the genesis of animal production systems in the context of agro-ecosystems, inherent biological attributes of goats, the main products that they produce, the socio-economic significance of rural production and processing centres, the marketing chains that are associated with the production to consumption continuum, the relevance of infrastructure and their collective contribution to food security. Specific features of the prevailing production systems are described: types of extensive systems (very extensive systems, extensive, landless, and nomadic and transhumance systems, migrations and agro-pastoralism), systems combining annual crops and arable cropping, and tree crops with ruminants. Of these however, the most important are the various extensive systems, due to the presence of large populations of ruminant animals, notably small ruminants, cattle and camels, and also a smaller proportion of buffaloes. Additionally, the type and density of animal populations on the quality of agricultural land, and extent of available feed supplies dictate the effectiveness of production systems.

The review will give emphasis to goats, but not exclusively, since most small farmers tend to manage mixed flocks of both goats and sheep and invariably herd and manage them together. The focus on goats is aimed at giving more prominence and discussion on this species, increase awareness of its many unique attributes, contribution to products and services, value addition of their by-products, improved livelihoods, potential productivity and food security.
Specific treatment is given to feed availability and feeding behavior in view of its dominant influence on production. Attention is drawn however to a summary of the main comparative characteristics of the two species, and for convenience subdivided and tabulated into body characteristics, distribution and preferred environment, nutrition, function, reproduction and diseases [7]. These features represent, as far as the author is aware, the main distinctive comparative characteristics which are apparent.

A major conclusion of the review was the extreme paucity of data on the various facets of the supply and value chains for meat, and very meager R and D on the subject in most countries in Asia. India is the exception, since much of the credit of what little is known presently goes to the Central Leather Research Institute (CLRI) in Chennai, India. The initiative to understand the marketing of small ruminants and meat handling systems started with a very large Government of India mandated study to CLRI on Raw Hides and Skins markets [8], and a two-phased research and development (R and $\mathrm{D})$ project on Meat Handling Systems which was supported by the Canadian International Development Research Centre (IDRC) for approximately six years (1992-1997). Very useful baseline information and experiences were generated about what is known presently concerning the status of the marketing of small ruminants, slaughter, and meat handling and processing in India. The study enabled useful field experience in conducting large-scale surveys of various types and sizes of farms, and learning about participatory work with farmers and the landless.

\section{Inherent Attributes of Goats and Production Systems}

The following points highlight inter alia the attributes in goats and their potential value:-

- The numerical dominance of the species throughout the developing world is conspicuous. In Asia this is in the ratio of about to 1.8 goats to 1 sheep

- About $41.5 \%$ of the goat population is found in the semi-arid/arid AEZs. The larger numbers of goats relative to the sheep in the more drier and less favored areas (LFAs) are also consistent in the presence of the poorest of the poor and extreme poverty

- The goat population accounts for about $36 \%$ of the total number of grazing animals (buffaloes+ cattle + goats + sheep)

- Their unprecedented powers of adaptation are unique, and this trait alone explains to large degree their extremely wide distribution across all AEZs- from the deserts to super humid environments

- The values in the meat trade of total edible proportion: is about $61 \%$, and total saleable proportion between $82-100 \%$. These data are much higher than similar data for sheep

- Goats have an inherent ability to use coarse fibrous feeds much more efficiently than sheep. Many studies confirm this point [9].

- Goats generally command a significantly higher price for their meat than mutton probably because of the higher lean meat content.

- The species is also endowed with an inherent relatively higher fertility status compared to sheep. The implications are more numbers born, increased number of animals for slaughter, meat and skins output and extent of profitability.

- Goats are very intelligent, nimble and have leadership qualities for which reason farmers tend to mix both goats and sheep so that the goats can lead the sheep to feed resource sites and grazing areas. 
- Extensive goat production is invariably found in fragile environments were also poverty is extreme. Thus, it has been suggested that goats can be the entry point for the development of the LFAs [10], recognizing also that agricultural growth is a prerequisite for economic development.

\section{Goat Genetic Resources: Diversity, Distribution and Productivity}

The world population of goats is approximately 1127 million in 2013 [11], and includes a total of 570 breeds. Asia is the most dominant region for goat production with the goats distributed across all ecosystems. Along with the total world population of goats found in these systems, together with sheep numbers form, these together provide invaluable resources especially for resource-poor farmers and the landless. The species has the largest populations of approximately $60 \%$ (556 million) in Asia and the Pacific, followed by Africa (311 million). India (35.2\%), China (29.3\%) and Pakistan (12.0\%). These countries together account for $77 \%$ of the total world goat population, and $42 \%$ of the total breeds (Table 1). During the period of 1985-2012 in Asia, the annual goat population growth rate was $0.5 \%$, with 146 breeds, and a $26 \%$ of the total breed share. Many of the European goat breeds have been widely introduced into many Asian countries, notably the Anglo-Nubian and the Saanen.

In the developing countries there also exist over 30 potentially important indigenous "improver breeds", 15 of which are located in Asia. These "improver breeds" have such important traits as meat, milk, fibre or skins producing capacity, and are therefore potentially important for enhancing goat production. "Improver breeds" are defined as potentially important and have the capacity to make a special genetic contribution e.g. growth rate, have above average performance, can enhance productivity, and are specially adapted to a difficult environment e.g. semi-arid /arid AEZ [2].

These breeds are underestimated but are important genetic resources with many useful attributes, and merit much more development attention to benefit from their potential worth (Table 1).

\begin{tabular}{|c|c|c|c|c|c|c|}
\hline \multirow[t]{2}{*}{ Region } & \multicolumn{2}{|c|}{ Year } & \multirow{2}{*}{$\begin{array}{c}\text { As \% of } \\
\text { total in } \\
2010\end{array}$} & \multirow{2}{*}{$\begin{array}{l}\text { Average } \\
\text { growth } \\
\text { rate } \\
\text { (\%/yr.) }\end{array}$} & \multirow[t]{2}{*}{ Breeds } & \multirow{2}{*}{$\begin{array}{l}\text { Breed } \\
\text { share } \\
(\%)\end{array}$} \\
\hline & 1986 & 2010 & & & & \\
\hline Africa & 105 & 310.7 & 33.7 & 2.8 & 89 & 16 \\
\hline $\begin{array}{l}\text { Asia and } \\
\text { Pacific }\end{array}$ & 254 & 556.1 & 60.4 & 2.3 & 146 & 26 \\
\hline Europe & 10.8 & 16.5 & 1.9 & 1.4 & 147 & 33 \\
\hline $\begin{array}{l}\text { Latin } \\
\text { America and } \\
\text { the } \\
\text { Caribbean }\end{array}$ & 32.9 & 212.6 & 4.8 & 22.8 & 34 & 6 \\
\hline Near East & 83.9 & 267.5 & 2.3 & 9.1 & 94 & 16 \\
\hline $\begin{array}{l}\text { North } \\
\text { America }\end{array}$ & 1.8 & 3 & 0.1 & 1.7 & 20 & no \\
\hline Total & 488 & 920.6 & - & 7 & 570 & 100 \\
\hline
\end{tabular}

Table 1: Goat populations, breeds and their global distribution [11].

\section{Meat and dairy goat breeds}

Within the diversity of goat genetic resources, Asia has a $26 \%$ share of goat breeds in global terms, equivalent to 146 indigenous breeds (Table 1). Approximately $94 \%$ of these breeds are meat breeds, whose presence is consistent with the fact that meat is the most important product derived from goats - in all countries in Asia, without exception [12]. By comparison, dairy goat numbers are significantly less, and only 13 breeds in Asia are considered to be truly identifiable dairy breeds [13] (Table 2). Table 2 also identifies "improver breeds". These breeds are also low to medium milk producers. Many of the "improver breeds" have not really been used outside their country of origin. Additionally, 13 dual-purpose (meat and milk) not well known goats exist, with variable milk yields.

\begin{tabular}{|c|}
\hline Potential "Improver Breeds" in dairy goats \\
\hline Ma T`ou* \\
\hline $\begin{array}{l}\text { Barbari*, Beetal, Chegu*, Gaddi*, Jamnapari, Jakhrana, Malabar, Marwari*; } \\
\text { Sangamnari* }\end{array}$ \\
\hline Etawah (Jamnapari) \\
\hline Bujri, Chapper ${ }^{*}$, Damani, Dera din Panah, Jattan, Jarakhell \\
\hline $\begin{array}{l}\text { Kachari", Kamori, Koh-I Ghizer, Kacchan*, Kajli", Kuranasari*, Kurri, Labri”, } \\
\text { Patteri }\end{array}$ \\
\hline Bach Thou* \\
\hline
\end{tabular}

Table 2: Asian dairy goats and potential. * "Improver Breeds".

\section{Distribution across agro-ecosystems}

In the various AEZs, there exist diverse and relatively large individual animal populations. These are widely distributed across small farms, which are the reservoirs of a large proportion of the main animal species. It is estimated that $90 \%$ of the ruminant livestock (buffaloes, cattle, goats and sheep) are found in the rainfed mixed farms. Native pigs and chickens are also very common and contribute significantly to food security.

Table 3 gives an idea of the diversity of the available ruminant species and their wide distribution in different parts of Asia. The majority of the goats are dispersed on small farms, which in Asia account for $67 \%$ of the 525 million small farms worldwide $(<2$ hectares in area) [14]. This excludes the several million landless farmers and agricultural laborers who rear goats [12]. Small farmers are more competitive with the marketing of ruminants than non-ruminants [15]. Concerted breeding and conservation efforts of indigenous goat breeds are also a means of mitigating climate change effects, with associated benefits in the trade of live animals and produce.

\section{The Genesis of Animal Production Systems}

The genesis of animal production systems provides good understanding of the demographic and economic changes that drive the evolution of the production systems within- regions and across AEZs. They also enable the development of methodologies for the assessment of greenhouse gas (GHG) emissions. It helps to keep in perspective the dynamics and evolution of the systems that are relevant in this case to goats and sheep, and the implications for improved, environmentally sustainable production systems.. Cropanimal systems form the backbone of Asian agriculture, have evolved 
and developed over many centuries. The principal determinants of the type of crop and animal systems that are found in a particular location are the agro-ecological conditions. Climate, and to a lesser extent soils, affect the natural vegetation and determine what crops can be grown. These in turn determine the feed base and its types, quantity, quality and distribution. The feed base, together with the disease challenge, governs the development of potential animal production systems. Feed resources and their diversity provide a direct link between crops and animals and the interaction of the two largely dictates the development, intensification of animal production systems and productivity from animals [16]. Animal-agriculture involves the sustainable management and efficient use of the natural resources that can enable maximum productivity.

\begin{tabular}{|c|c|c|c|c|c|c|c|c|}
\hline \multirow{3}{*}{ Sub-region } & \multicolumn{8}{|c|}{ Agro-ecosystem and animal species } \\
\hline & \multicolumn{2}{|c|}{ Lowland irrigated } & \multicolumn{2}{|c|}{$\begin{array}{l}\text { Lowland/upland } \\
\text { Rainfed }\end{array}$} & \multirow{2}{*}{$\begin{array}{l}\begin{array}{c}\text { Semi-arid/and } \\
\text { arid }\end{array} \\
\text { Goats/ } \\
\text { sheep }\end{array}$} & \multicolumn{3}{|c|}{ Highlands } \\
\hline & $\begin{array}{l}\text { Buffalo/ } \\
\text { Cattle }\end{array}$ & $\begin{array}{l}\text { Goats/ } \\
\text { sheep }\end{array}$ & Buffalo/cattle & Goats/sheep & & & Cattle & Goat/ sheep \\
\hline China & $\star \star \star *$ & * & ** & $* * *$ & * & $2 * *$ & $* *$ & $* * *$ \\
\hline Hindu-Kush & $* * *$ & * & ** & $* \star *$ & * & - & * & $* * *$ \\
\hline S, Asia & $* * *$ & * & ** & $* \star \star$ & * & 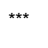 & * & * \\
\hline Mekong countries & $* * *$ & * & ** & ** & ** & * & * & * \\
\hline S.E, Asia & $* * *$ & * & ** & ** & * & ** & * & * \\
\hline
\end{tabular}

Table 3: Distribution of domestic animals by ecosystem and sub-regions in Asia. ${ }^{\star}$ Low concentration; ${ }^{\star \star}$ Medium concentration; ${ }^{\star \star \star}$ High concentration

Figure 1 illustrates the genesis of livestock systems in which the key ones are very extensive and extensive systems, systems combining animals and annual and perennial cropping type a comprehensive account of these systems has been described [17]. Livestock systems are a function of the agro-ecological conditions and prevailing farming systems. The key AEZs include the arid and semi-arid, humid and subhumid, and highland and temperate regions.

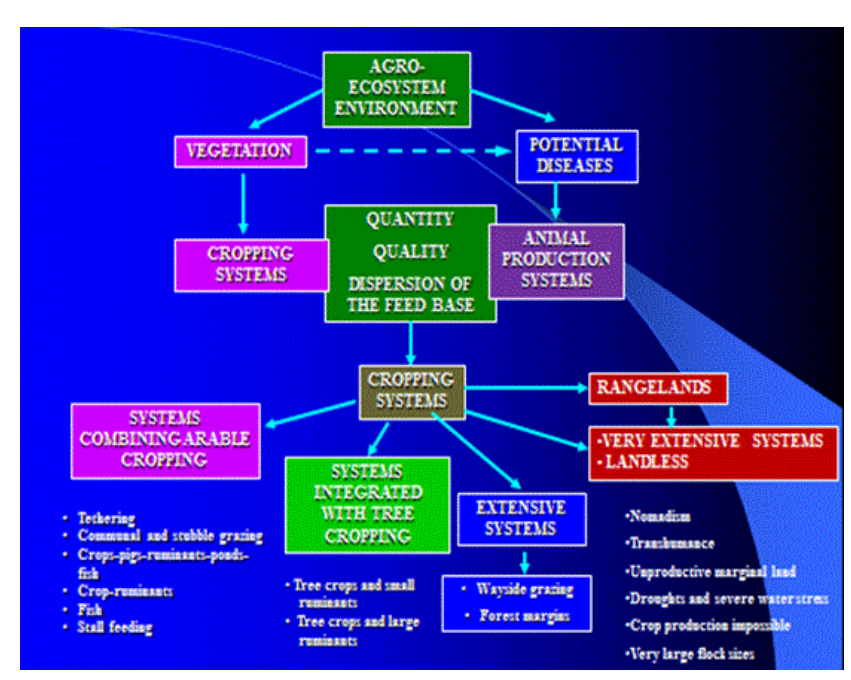

Figure 1: Genesis of animal production systems in Asia.

Climate, edaphic and biotic factors determine whether cropping is feasible, which in turn determines the link with animals through the quantity and quality of feeds produced [16]. It is interesting to note that indigenous knowledge and community-based participation have also influenced the evolution and development of improved systems and system perspectives.

Together with ecological and environmental factors which determine livestock systems, social and economic issues also exert much influence on the development of other systems. Injecting large capital inputs and imports for example, can shift the level of intensification from a subsistence situation, and significantly increase the cost of production. Likewise, traditional land fragmentation into smaller areas as in China and Indonesia goes against potential intensification and survival. Thornton et al. [18] have reported that the extent of poor livestock keepers by production system and region, and several observations are relevant. Within these systems and withinregion, South Asia and South East and East Asia accounted for a 59 to $60 \%$ proportion of total poor livestock keepers. Mixed irrigated systems were the next highest, with a 29 to $33.7 \%$ proportion. The higher number of poor livestock keepers in the mixed farming systems in rainfed areas is consistent with the higher proportion of the rural poor found in the combined marginal, arid lands, forests and woodlands.

Two important factors are associated with the dynamic nature of animal production systems: diversification and intensification. Diversification is the process of spreading the production resources and enterprises, for example crops and animals, to reduce risks and losses, to seek efficiency, economic benefits and sustainable production even at the subsistence level. Aside from minimising risks, agricultural diversification in small farms is directly associated other key issues, namely rainfall, seasonality and sustainable use of the prevailing natural resources. The development of integrated tree cropruminant systems is a good example of diversification in which two sub-sectors are well integrated with many biological and economic benefits e.g. reduced fertiliser use, effective use of the forage biomass, and increased yield of the parent crop. 
Intensification on the other hand involves large capital and other resource inputs e.g. imported grains. The spectacular growth of the pig and poultry industries and self-sufficiency in several countries in such as China followed by dairy development in India are good examples of this process., With ruminants, intensification will involve a shift from the extensive systems progressively to the more intensive systems that can potentially be developed, provided the process is in close proximity and has accessibility to sizeable and constant supplies of feed resources, application of yield-inducing technologies, and an expanding market demand. In turn they will influence such other issues as $\mathrm{C}$ sequestration and GHG emissions.

Successful and demonstrable intensification will be ultimately reflected in terms of maximum efficiency and productivity in the use of natural resources to the extent possible [19]. Intensive systems are of particular importance for two reasons. Firstly, it's here that changes are occurring most rapidly and allow opportunities for interventions and improvements. Secondly, much information will be forthcoming due to the possible implications and impacts of intensification on poverty alleviation, livelihoods, animal diseases, public health and the environment [20]. The replicability of proven technologies will have significant wider impact on productivity from animals.

The largest numbers of rural poor work in the mixed crop-animal systems. Thus improving the sustainable livelihoods of these people has a direct effect on reducing poverty than increasing productivity in intensive industrial systems. The rainfed and irrigated mixed cropanimal systems are priority areas for development and are particularly significant in South East Asia, West Asia, North Africa and West Africa. The trend In South East Asia is that the increased production of meat will come from intensive industrial pig and poultry production systems that depend largely on imported grain. By comparison, increased and more assertive resource use, well defined agendas, priority $\mathrm{R}$ and $\mathrm{D}$ and wide application are necessary to enhance increased production from ruminants. The strategy needs necessarily to keep pace with consumer demand and enhance productivity per animal, reduce losses and wastage starting from production through to consumption.

\section{Types of Extensive Systems}

In agricultural systems there is no one generic system that can comprehensively describe all the complex types of farming activities [21]. Types of extensive systems represent the resultant interactions between ecological, biophysical and socio-economic factors. Agroclimates, based mainly on temperature and length of growing season (LGP) provide an important pathway to assess the influence of the biophysical environment and the implications of these interactions.

The agro-climate categories of relevance are:-

- Arid and semi-arid $[<180$ days]

- Humid and sub-humid [>180 days]

- Tropical highlands or temperate. Tropical highlands are defined as those areas with a daily mean temperature during the growing period of $5-20^{\circ} \mathrm{C}$.

Three broad systems are identified in extensive systems. In comprehensive terms, the following features are relevant:-
- Involves large areas of unproductive and marginal land, essentially less-favored

- Land that cannot support crop production, due to low total rainfall

- Very sparse vegetation is common

- Systems are continuously affected by droughts and severe water stresses

- Has the largest flock sizes $>1000$ small ruminants

- Stocking rates are very low : $<0.5$ animals/ha

- Limited potential for intensification

- Feed scarcity and under - nutrition are major problems and priorities for research

- Animal-agriculture is potentially important

- The poorest of the poor and the landless are found here

- Animals provide some food security, survival and hope, and

- Lack of, or inability to control animals will result in severe damage to the environment and in addition, animals become feral, and assume pest proportions.

Rangeland-based systems embody most of these features, and are found mainly in the semi-arid and arid regions of South Asia and China. Sparse vegetation, containing mainly native grasses and shrubs are characteristic of this area. These however are important sources of feeds In Pakistan, some 65\% of the total land area, from altitudes of 0$>4000 \mathrm{~m}$ is rangelands, and it is estimated that $60 \%$ and $5 \%$ of the total feed requirements of small ruminants and large ruminants respectively are met by the rangelands [22]. These areas support very low carrying capacities of 3-5 sheep per hectare such as is found in the Baluchistan Province of Pakistan. Three major concerns about rangeland-based systems are the need for strategies to use of common property grazing lands, communal management of these lands, and coping with drought feeding.

\section{Extensive}

Nomadism

Transhumance

- Is the most common and most widely used system

- Are not seasonal (Grazing and housing daily)

- Also classified as semi-intensive and are intermediate between very extensive and intensive

- Management of mixed goat and sheep flocks are common

- Smaller flock sizes (20-200 animals)

- Stocking rates are around 1-4 animals per ha

- Intensity of use is dependent on type of AEZs, feeds and water availability

- Type of AEZ (Semi-arid vs. Humid) influences management practice.

- Wide application of several loss minimizing strategies are apparent e.g. herd diversification, household survival mechanisms, off farm activities and increased investments

- Droughts and water stresses are common and good potential exists for the development of intensification.

\section{Very extensive}

- Regular droughts and climate instability 


\section{Landless nomadic and transhumance systems}

- Is the oldest but important type of migratory system for goats and sheep

- Unlike the extensive systems, nomadic and transhumance systems are more seasonal

- Involves regular movement of whole families and flocks of goats, sheep and camels in constant search for grazing and water

- Movements are based on years of experience

- The movements are not haphazard and following well defined routes are common

- Flocks are regularly moved in familiar annual migration routes from winter grazing areas to summer grazing areas in the highlands and mountains

- Flocks of goats and sheep move in well-known routes on fixed dates

- Flock owners have a permanent base where the animals are grazed for about half a year, and then migrate with their flocks to other regions for the rest of the year

- The common system in mountain country is wintering in the valley and or the desert and then shift to graze the high mountain pastures in summer

- The availability of grazing and water determines a pause in the movements

- Due to long tradition, farmers recognize grazing rights over their territory, and

- Quite often the movements involve the process of folding that is the return of dung and urine to fertilize farmer's fields in return for cash or produce.

\section{Migrations}

In general, migrations are common, are a way of life, and farmers use these strategies to reduce risks of losing animals and be able to cope with extreme weather conditions. The migratory systems are triggered by very high temperatures, inadequate feeds and water. The migrations are of four categories; (i) nomadic, (ii) transhumance, (iii) partial settlement and (IV) and full settlement. During this process, some of the rich farmers buy animals at reduced prices from those who are unable to manage the animals, resulting in heard expansion.

Temporary migrations for very short periods are triggered mainly by lack of feeds, grazing and water. The semi-permanent migration resembles the temporary method, except that the duration is longer, before they return to their original abode. Permanent migration is distinctly different in that there is no return to from where they started. 'Home' is wherever there is access to feeds and water. Lopping of trees is well known and very common, to supply dietary fodder e...g. Acasia spp., Prosopis cineraria and Azadirechta. The migrants usually follow familiar and well known routes. In Tamil Nadu in India, the route is Pudukottai, Tanjore, Trichy, South Arcot, and Thiruvannamalai. Depending on rainfall and available grazing, they camp for 2-3 weeks before moving on. In western Rajasthan, which is essentially an arid AEZ, migrations are a must because of the extremely high temperatures $\left(>43^{\circ} \mathrm{C}\right)$ during the summer months. The small ruminant flocks regularly enter the Punjab, Haryana, Uttar Pradesh and Madhya states. For most of these poor farmers and the landless, migrations are part of their life.

The migrations are usually long caravans and are spectacularly colorful. The permanent migrations are transhumance systems and are one of the most important extensive systems. The systems are very spectacular and are a common occurrence in northern India. Flocks are moved on a regular annual migration from the established winter grazing areas, to summer grazing areas in the highlands and mountains. The system is very common in cold arid and semi-arid regions of Asia. It has evolved for the occupation of these large areas of the available sparse grazing, and permits movement of the animals according to the seasonal availability of feeds. The migratory system has two sub-divisions: transhumance and nomadic.

Of particular interest is that whole households are involved and on the move along regular established routes. Very often communal parties are involved along with their goats, sheep, cattle and invariably camels. The men and small ruminant flocks lead the way, and behind them trail the camels with their lazy trundling bulk of the main household items: furniture, charpoys (light bedstead), pots and pans, grindstones, and bagfuls of grains. The women and the children in colorful attire ride majestically on the camel's back.

\section{Feeding Behavior of Goats in Extensive Environments}

\section{Feeding behavior}

Available feed resources, value in feeding systems, effective utilization and feeding behavior together represent major factors in maximizing productivity and economic animal production. Among the factors influencing production, particular emphasis needs to be given to the key influence of the use of good quality feed resources. In this context, it is essential to keep the following key issues in perspective:-

- Full knowledge of the availability and potential use in production systems that can give predictable levels of performance

- Identification of the objectives of production clearly in terms of potential use, production and profitability

- Recognize that the cost of feeding in individual animal production systems as percentage of total production costs is relatively high and rising, and

- Work towards self-reliance in the use of available feed resources

The feeding behavior of goats is quite distinctive. The distinctiveness stems from their mouth parts which are different to that of other ruminants, preference for shrubs and tree leaves, and their very selective, discerning and choosy behavior. This also relates to increased efficiency in the use of coarse roughages in that wide selection enables extension of their feed preferences and meeting their nutrient requirements. Hence the concept that the value of goats especially for the resource poor, increases with decreasing quality of grazing and availability of feeds.

Table 4 tabulates the more important details and features about the feeding and nutrition in goats. To provide greater focus and understand diference's on the subject, a comparison with sheep has also been made. Farmers in Asia, often herd both species together in extensive grazing systems knowing that goats are more discerning about areas where feeds are available, can walk long distances and lead the sheep.

The longer distances walked by goats is specific to the arid and semi-arid AEZs in search of feed and water, and involves at least twice the distance compared to the more sedentary goats in the sub-humid and humid environments. The tendency of goats to walk longer distances is due mainly to their inquisitive feeding habits, intense 
selection and browsing habits with a will to meet their nutrient requirements. Thus goats tend to walk longer distances than sheep. However, the longest distances walked are by camels, with progressively lesser distances walked by goats, sheep and cattle. This pattern is consistent with the fact that both camels and goats adapt much better to feat stress and very low planes of feed availability and nutrition utilizing desert shrubs and coarse roughages. Both species also have anatomical advantages (Table 5), which in the case of the camel concerns the long neck.

\section{Dietary browse}

The value of goats to be productive in harsh and semi-arid and arid environments in comparison to sheep is associated with a number of important factors. These include: full adaptation to heat, heat stress, and in warm climates have the ability to conserve body water. Long legs are common; to enable the goats to walk long distances in search of feeds, and enable the udder to have good ground clearance. In addition, goats have special mouth parts, and very good capacity and ability to make good selection and intake of a wide variety of feeds, and higher digestive efficiency of coarse roughages [9].

In the rangelands of northern Pakistan for example, some $65 \%$ of the total land area, from altitudes of $0->4000 \mathrm{~m}$ is rangelands, and it is estimated that $60 \%$ and $65 \%$ of the total feed requirements of small ruminants and large ruminants respectively are met by the rangelands [22]; goats survive almost exclusively on browse. In Mexico, observations on a mixed brush-grass-forb community revealed that 83 of the bites by goats were on browse and $17 \%$ were on grass [23]. The species is therefore very important for reasons of security and survival of the resource-poor and small farmers in these environments. Their capacity to utilize the herbage biomass effectively in these very harsh environments provides an important means of ensuring productivity and livelihoods.

\begin{tabular}{|c|c|c|}
\hline Characteristics & Goats & Sheep \\
\hline Activity distances & Bipedal stance and walk longer & Walk shorter distances \\
\hline Feeding pattern & Browser, more selective & Grazer, less selective \\
\hline Browse and tree leaves & Relished & Less relished \\
\hline Variety in feeds & Greater preference & Smaller preference \\
\hline Taste sensation & More discerning & Less discerning \\
\hline Salivary secretion rate & Greater & Moderate \\
\hline Recycling of urea in saliva & Greater & Less \\
\hline $\begin{array}{l}\text { Dry matter intake: } \\
\text { - for meat } \\
\text { - for lactation }\end{array}$ & $\begin{array}{l}3 \% \text { body weight (BW) } \\
4-6 \%(\mathrm{BW})\end{array}$ & $\begin{array}{l}3 \%(\mathrm{BW}) \\
3 \%(\mathrm{BW})\end{array}$ \\
\hline Digestive efficiency of coarse roughages & Higher & Lower \\
\hline Retention time & Longer & Shorter \\
\hline Water intake/unit Dry matter intake & Lower & Higher \\
\hline Rumen NH3 concentration & Higher & Lower \\
\hline $\begin{array}{l}\text { Water economy } \\
\text { - Turnover rate }\end{array}$ & $\begin{array}{l}\text { More efficient } \\
\text { - lower }\end{array}$ & $\begin{array}{l}\text { Less efficient } \\
\text { - higher }\end{array}$ \\
\hline Fat mobilization increased during periods of feed Shortages & More evident & Less evident \\
\hline $\begin{array}{l}\text { Dehydration } \\
\text { - Faeces } \\
\text { - Urine }\end{array}$ & $\begin{array}{l}\text { Less water loss } \\
\text { More concentrated }\end{array}$ & $\begin{array}{l}\text { Relatively high water } \\
\text { Less concentrated }\end{array}$ \\
\hline Tannins & More tolerance & Less tolerance \\
\hline
\end{tabular}

Table 4: Comparative feeding behavior and digestive physiology in goats and sheep [9].

Browse is an important and often the main feed resource in semiarid and arid regions in Asia, Sub-Saharan Africa and Latin America. Browse refers to the tender shoots, twigs sand leaves of shrubs and woody plants, fruits and pods; their value to goats and sheep is especially significant because of the sparse feed resource base.
Browse is an important component of the diet of goats, and its use is closely linked to the feeding habits especially in extensive production systems such as in the rangelands. In these environments, browse forms a relatively large proportion of the daily dry matter intake of goats and ensures productivity. In this context, the results of [24] are noteworthy. Animals with esophageal fistula were used, and feed preferences measured of captive feral goats compared with sheep, 
Citation: Devendra C (2015) Dynamics of Goat Meat Production in Extensive Systems in Asia: Improvement of Productivity and Transformation of Livelihoods. Agrotechnol 4: 131. doi:10.4172/2168-9881.1000131

Page 9 of 21

at three grazing pressures $(0.5,0.25$ and 0.17 animals/ha). At low stocking rates, sheep at $80 \%$ herbs and $20 \%$ browse, while goats ate the reverse; at medium and high stocking rates, availability of herbs governed intake. Goats tended to select diets with apparently higher nitrogen content than did sheep. Similar results have also been reported from Africa and Latin America.

A production system that is very important but underestimated, concerns silvopastoral systems. These systems are an important means of diversification, intensification and protection of the environment [25].[26] have calculated that in mixed farming systems, the $C$ sequestered was $0.32 \mathrm{tic} / \mathrm{ha} / \mathrm{yr}$, and $\mathrm{ADB}$ [27] has reported that mitigation can potentially sequester $\mathrm{C}$ by $3.04 \mathrm{tCO}_{2} / \mathrm{ha} / \mathrm{yr}$, reduce $\mathrm{CH}_{4}$ emission by $0.02 \mathrm{tCO}_{2}-\mathrm{eq} / \mathrm{ha} / \mathrm{yr}$, and reduce $\mathrm{N}_{2} \mathrm{O}$ emissions by $0.02-2$, $30 \mathrm{CO}_{2}-\mathrm{eq} / \mathrm{ha} / \mathrm{yr}$ Agronomic practices have great potential to enhance the $\mathrm{C}$ sinks and enrichment of soil organic matter through leguminous trees e.g. Leucaena leucocephala.

\begin{tabular}{|c|c|c|c|}
\hline \multicolumn{2}{|c|}{ South Asia } & \multicolumn{2}{|c|}{ South East and East Asia } \\
\hline Common name & Botanical name & Common name & Botanical name \\
\hline Anjan & Hardwickia binnata & Banana & Musa spp. \\
\hline Ardu & Alilanthus excels Roxb. & Banyan & Ficus bengalensis \\
\hline Babul & Acasia arabica & Canna & Canna spp. \\
\hline Bauhinia & Bauhinia spp. & Cassava & Manihot esculenta Crantz \\
\hline Banana & Musa spp. & Flemingia & Flemingia macrophylla \\
\hline Bargad or anyan & Ficus bengalensis & Gliricidia & Gliricidia spp. \\
\hline Beri & Ziziphus jujube & Hibiscus & Hibiscus rosa-sinensis \\
\hline Dhanicha & Sesbania aculeaton & Jackfruit & Artocarpus heterophyllus \\
\hline Gular & Ficus glomerata & Lantana & Lantana spp. \\
\hline Imli & Tamarindus indica & Leucaena & Leucaena leucocephala \\
\hline Jackfruit & Artocarpus heterophyllus & Passion fruit & Pasifloraedulis $f$. flarcarps \\
\hline Jamun & Engeinia jambolana & Pigeon pea & Cajanus cajan \\
\hline Kheiri & Prosopis cineraria & Sesbania & Sesbania grandiflora \\
\hline Khair & Acasia catechu & $\begin{array}{l}\text { Sweet potato } \\
\text { vines }\end{array}$ & Ipomoea batatas \\
\hline Khantal & Artocarpus integrifolia & Erythrina & Erythrina poeppigiana \\
\hline Mulberry & Morus indica & Mulberry & Morus indica \\
\hline Pakar & Ficus infectoria & Neem & Azadirachta indica \\
\hline Pipal & Ficus religiosa & Mung bean & Vigna radiate \\
\hline Neem & Azadirachta indica & Cowpea & Vigna unguilata \\
\hline Sainjan & Moringa oleifera & Desmodium & Desmodium heterophyllum \\
\hline Siras & Albizzia lebbeck & Groundnut & Arachis hypogaea \\
\hline Atriplex & Nummularia & Tamarind & Tamarind indica \\
\hline
\end{tabular}

Table 5: Some important tree leaves and browse plants used by goats and sheep in Asia.

- In the oil palm environment there exists considerable variety in the available forage biomass, which is advantageous to favor intake by goats

- Forage dry matter availability: $2.99-2.16 \mathrm{tm} / \mathrm{ha}$ for 3 and 5 year old palms reducing to $435-628 \mathrm{~kg} / \mathrm{ha}$ for 10-29 year old palms [28]

- 60-70 forage species in young palms, which are reduced by about $66 \%$ in older palms
- Forage categories: 56-64\% grasses, 18-23 dicotyledons, 3-19\% legumes and $2-15 \%$ ferns for 3-10 year old palms, and 50\% grasses, $13 \%$ dicotyledons, $2 \%$ legumes and 35\% ferns [29], and

- About $72-93 \%$ of the forages are palatable and of value to ruminants.

In view of the importance of leguminous browse, tree leaves and their use in inexpensive feeding systems for goats in Asia, Table 6 identifies the names of the more important of these in South Asia, 
Page 10 of 21

South East Asia and East Asia. Most of the local names for goats are combined with the planting of rice. The list is by no means exhaustive and there are many more indigenous varieties that are used by goats and sheep. Many of these forages are also used in Africa and Latin America, and the benefits to ruminants are consistent across ecoregions [4].

For comparative reasons, Table 6 summarizes the range and types of feeds that are potentially useful for goats and sheep. The table highlights the types of feeds available and is used across AEZs in individual types of production systems. What types of feeds are found are specific either to the semi-arid or sub-humid to humid ecoregions. The feeds include browse, tree leaves and various grasses.

\section{Goat Meat Production}

Meat is the most important product from goats and sheep throughout Asia and elsewhere. With goats, meat production is the primary function in the developing countries, followed by milk. This is reflected in the demand for their meats, which in all countries is income elastic. In many countries in Asia such as Malaysia and Bangladesh, the cost of goat meat is about two times higher than that of mutton, most of which is imported from elsewhere [12].

\begin{tabular}{|c|c|c|c|c|c|c|c|}
\hline \multirow{2}{*}{$\begin{array}{c}\text { Type of } \\
\text { livestock } \\
\text { system }\end{array}$} & Priority & \multicolumn{5}{|c|}{ Eco regions } & $\begin{array}{l}\text { Major } \\
\text { examples of } \\
\text { dietary } \\
\text { forage }\end{array}$ \\
\hline & system & Asia & SSA & CA & WANA & LAC & \\
\hline \multirow{4}{*}{ 1. Landless } & $\begin{array}{l}\text { Peri-urban/ } \\
\text { urban dairy } \\
\text { production }^{* *}\end{array}$ & * & * & * & * & * & $\begin{array}{l}\text { Guinea grass } \\
\text { (Panicum } \\
\text { maximum)+ } \\
\text { Leucaena) }\end{array}$ \\
\hline & $\begin{array}{l}\text { Peri-urban/ } \\
\text { urban poultry } \\
\text { and pig } \\
\text { production }{ }^{* * *}\end{array}$ & * & * & * & * & * & $\begin{array}{l}\text { Poultry- } \\
\text { concentrates } \\
\text { Pigs- } \\
\text { concentrate } \\
\text { +sweet } \\
\text { potato vines }\end{array}$ \\
\hline & $\begin{array}{l}\text { Feedlot } \\
\text { (cattle or** } \\
\text { small } \\
\text { ruminants) }\end{array}$ & * & * & * & * & * & $\begin{array}{l}\text { 1. Oil palm } \\
\text { by-products } \\
\text { 2. Guinea } \\
\text { grass } \\
\text { +mungbean }\end{array}$ \\
\hline & $\begin{array}{l}\text { Goat and } \\
\text { sheep } \\
\text { production* }\end{array}$ & * & * & * & * & * & $\begin{array}{l}\text { 1. Wayside } \\
\text { grazing } \\
\text { 2. Lopping } \\
\text { tree leaves }\end{array}$ \\
\hline $\begin{array}{l}\text { 2. Crop- } \\
\text { based } \\
\text { mixed } \\
\text { farming }\end{array}$ & $\begin{array}{l}\text { Integrated } \\
\text { systems with } \\
\text { annual crops } \\
\text { (ruminants } \\
\text { and non- } \\
\text { ruminants } \\
\text { plus fish) }\end{array}$ & * & * & * & * & * & $\begin{array}{l}\text { 1. Food-feed } \\
\text { systems } \\
\text { e.g. and rice- } \\
\text { mung } \\
\text { bean/siratro } \\
\begin{array}{l}\text { Maize } \\
\text { cowpea }\end{array}\end{array}$ \\
\hline
\end{tabular}

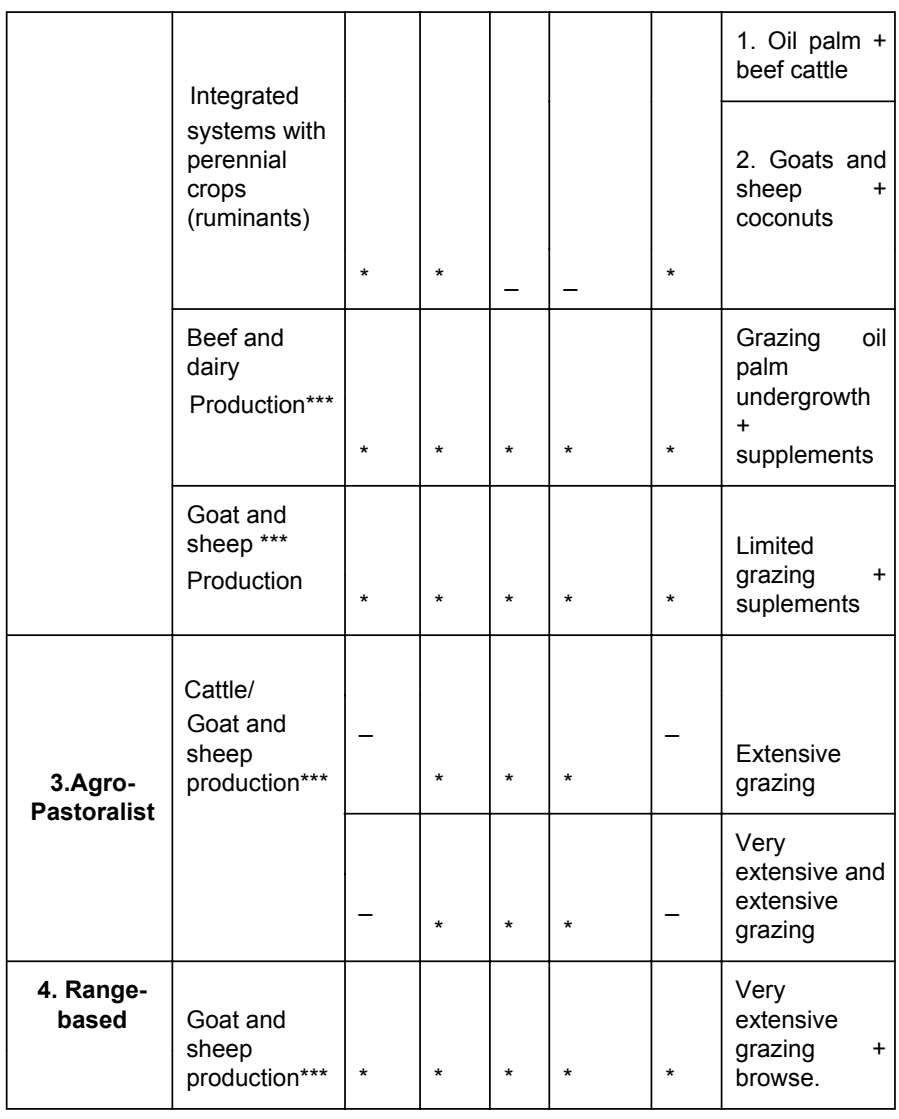

Table 6: Examples of forage biomass used across Ecoregions.

Notes: (i) SSA-sub-Saharan Africa; CA-Central Asia, WANAWest Asia and North Africa, LAC- Latin America and the Caribbean.

(ii) ${ }^{\star}$ Indicates that both the production systems and animal species are equally important within the region. Goat and sheep production refer mainly to extensive systems

(ii) ${ }^{* *}$ Refer mainly to semi-arid and sub-humid and sub-humd humid to humid AEZs

- Refer mainly to the semi-arid/arid and sub-humid/humid AEZs respectively.**

Table 7 summarizes trends in the volume of goat meat produced in Asia between 1985-2012. The total supply is the sum of production in South Asia, South East Asia and East Asia. Asia alone produced 72.6\% of the total global production, and over the period 1985-2012, the volume of contribution increased by $6.8 \%$ /year, much higher than the $6.0 \%$ for the world production.

The average carcass weight is a rough measure of the efficiency of meat production. The number of animals maintained will reflect the biological cost, and the amount of meat produced the returns. Improvements to the latter will indicate increased net return to the producers. In good breeding programs, increased meat production and numbers for local slaughter are associated with replacements in production systems that match efficient use of especially feeds. On the other hand, decreased production per head and increased numbers will indicate in the more extensive systems, overgrazing in the face of reduced feed supplies. 
An examination of carcass weight per head in the developing countries of Asia over the last three decades indicates that the average weight in sheep (14-16 kg) was higher than in goats $(12-13 \mathrm{~kg})$. The difference is due to the use especially of imported improved sheep breeds that have been selected for increased growth rate, better carcasses, crossbreeding, and application of improved technology from industrialised countries.

\begin{tabular}{|l|c|l|l|l|c|}
\hline $\begin{array}{l}\text { Production } \\
\text { (tonnes) }\end{array}$ & $\mathbf{1 9 8 5}$ & $\mathbf{1 9 9 5}$ & $\mathbf{2 0 0 5}$ & $\mathbf{2 0 1 2}$ & $\begin{array}{c}\text { Avg. } \\
\text { annual } \\
\text { growth } \\
\text { rate (\%) }\end{array}$ \\
\hline In Asia & 1281.6 & 2229.8 & 3236.7 & 3847.2 & 6.8 \\
\hline Total World & 2028.3 & 3237.7 & 4638.8 & 5300.8 & 6.0 \\
\hline
\end{tabular}

Table 7: Goat meat production in Asia (FAO, 2012, tonnes).

An analysis of the prices of goat meat and mutton in various countries in Asia indicated that with the exception of China and Indonesia where the prices were the same, in six countries (Bangladesh, India, Nepal, Philippines, Malaysia and Thailand), the difference was higher values for goat meat, and was in the range of $17-121 \%$. For goat meat, the highest price was in Malaysia and the lowest was in China. The lower price for mutton could well be associated with imported mutton from overseas, usually from unproductive and old animals with relatively larger content of body fat. For these reasons, it is possible that the total edible value is likely to be higher in goats compared to sheep. On the other hand, the total saleable proportions in both species are comparable.

Currently, meat is produced from sheer numbers available for slaughter at the abattoirs. These include both young (8-12 months old), mature and unproductive cull animals (six years and above). With goats, most of the animals slaughtered are at the younger end of the scale because of the very high market demand for goat meat. During some periods of the year, especially festivals, relatively more mature and especially fattened sheep are sold at much higher live weights. The key point in these circumstances is that numbers, and to a lesser extent live weight at slaughter, are the major driving forces for the sale of animals. Quality of animals or meat is not a consideration in the marketing of the animals. The market demand is thus mainly met by the availability of animals, which in turn also affects the relative prices of the meats. Uncontrolled sale of animals for slaughter has the serious effect of depleting breeding animals, disruption on large-scale breeding projects, erosion of the genetic base, and the inability of both species to sustain the need for numbers for meat production.

Associated with this situation is the rampant substitution of goat meat by both locally produced and imported mutton to benefit from the higher prices of goat meat. Often the consumer is put to a disadvantage with unscrupulous marketing and delivery of poorer quality mutton with a much higher content of subcutaneous fat. Goat meat by comparison, has most of the fat in the viscera.

It is pertinent to also draw attention to the considerable demand for these meats in Middle East markets. Several delegations and individuals have approached many countries in the Asian region to cope with this request, but most countries are not ready as yet, to respond to this potentially lucrative demand for goat meat and mutton.
Interestingly, the goat populations in all countries in Asia except China are higher than that of sheep. Goats are about $49 \%$ higher in numbers than that of sheep. The greater demand for goat meat and higher price for the meat, together with uncontrolled breeding and poor selection have resulted in increased extraction rates for slaughter. These together may have also contributed to the lower meat production per head in this species compared to sheep. In the Philippines, the sheep population is negligible in size compared to goats, with the latter growing at the fastest rate among all ruminant species by about $4.1 \%$ between $1990-2000$.

In these circumstances, it is relevant and compelling to ask how the efficiency of goat meat production can be improved, and specifically what can be done to improve the situation? Associated with this, it is also pertinent to ask what development strategies, together with the elements related to the buildup of numbers that need to be pursued to increase the level of small ruminant meat production? The sections following discuss these aspects.

An important prerequisite for improved efficiency of production involving increased quantity and better quality products is the need for clear production objectives. Concerning quantity, total amount of lean meat in the carcass, measured by live weight at slaughter, and total number of animals available for slaughters is important.

\section{Buildup of Numbers}

Increasing the buildup of numbers is a very urgent and high development priority Outside of Pakistan, India and China; many countries are constrained by sheer inadequate goat populations, caused by neglect of the species and high slaughter rates of animals for slaughter. This also facilitates improved breeding programs and selection to promote the efficiency of reproduction and meat production. Reproductive rate is the all too important component, and the buildup of numbers is associated with the following factors:-

(a) Age at first mating

(b) Number of years in the breeding flock

(c) Annual death rate in the breeding flock

(d) Number of females reared to breeding age each per 100 breeding does.

This is influenced by the following factors:-

- Per cent breeding does failing to conceive

- Per cent of breeding does producing multiple births

- Frequency of parturition (influenced by durations of gestation and post-partum anoestrus), and

- Death rates in young from birth to maturity.

Few national programs in the Asian region are concerned or given serious attention to the task of building numbers for breeding, but equally, important, making available adequate animals for growth and fattening for slaughter. Lack of attention exacerbates the objective of goat production making a significant contribution to productivity enhancement to meet national requirements for goat meat. In the absence of such concerted development, goat populations are subject to natural increase and the magnitude of slaughter of the base population. It is a serious issue, and since it constraints expanded development of goats, it merits critical review and improvement. 
Very valuable approaches and calculations have been made by Turner HN [30] to demonstrate how the build numbers can be achieved. The following assumptions were made:-

- Age at first mating (both sexes) $1 \frac{112}{2}$ years

- Number of years in breeding flocks: males 2; females 5.7,10

- Death rate in females in breeding flock: 5 and $10 \%$, and,

- Number of offspring reared to per 100 breeding females: 70, 110, 150, and 210. 250 and 290.

Using the above two calculations were made. The data in both figures are based on flock size of 100 breeding does.

(a) The number of breeding females present at the end of each successive year, starting with a flock of 100 and assuming all of these to be mated

(b) The number of surplus animals of each sex available each year from a flock of fixed size (taken as 100 breeding does) Surplus young bucks would be available for breeding elsewhere or for slaughter. Surplus young does would have to be distributed for breeding if the numbers in (a) were to be attained. Cull goats of both sexes would be available for slaughter.

Calculations were made using an initial flock of 100 to assess how much this would have increased after 10 years plotted against reproduction rate. Both numbers in the breeding flock and annual death rate have some influence on the final number reached, but obviously the main factor is reproduction rate. At the lowest level plotted (70\%) which might follow from 5-20\% females with twins, a low parturition frequency (1.0-1.3) and a high death rate in offspring means that the number of does in the breeding flock would have expanded to only approximately 230-540, depending on length of life and annual death rate.

With reproduction at $210 \%$ (attained with combinations of $20-60 \%$ does with twins, parturition frequencies from 1.5-2.0 and death rates of offspring from 5-20\%), the final number of breeding does after 10 years with $60 \%$ twins, 2 parturitions/breeding does after 10 years with $60 \%$ twins, 2 parturitions/year and only 5-10\% losses in offspring, the final numbers range from 8800-11,600. The numbers of cull does depend only on death rate and number of years in the breeding flock. For a life span of 5-10 years in the flock, the mortality is 17 and 8 respectively. The number of cull bucks depends on the ratio of bucks to does for breeding, and the number of times the buck are used. Assuming 4 bucks per 100 does, and half replaced annually, the number of cull bucks is two per year.

\section{Multi-Functionality: Products and Uses}

Goats contribute significant and extensive multipurpose functions of socio-economic and nutritional importance [31]. The products and functions are especially important for socio-economic benefits for households, the stability and benefits of prosperity poor farmers and the landless in Asia. Some idea of is reflected in Table 8. The slaughter of goats also results in a variety of products, by-products, uses, and more importantly, value addition to these. These will vary from country to country, but the fact remains that there is economic value extensive use of the materials.

The marketing of goats starts at the farm with the owners and producers of these. The farmer sells the animals at the farm gate, and expects payments for his produce before the animals leave his possession. Alternatively, some financial arrangements are made to cover the various costs involved. To keep transaction costs low, the marketing pathways are kept short.

\section{Types of markets}

There are three broad types of markets concerned with the marketing of goats. These are as follows:-

(i) Assembling markets

(ii) Distribution markets, and

(iii) Weekly markets

The assembling markets are the focal points for the centralised concentration of the animals from the farm for their sale and collection. They are integrated complexes with live animal market and by-product processing plants With goats, these are often sold along with sheep because of the fact that are often reared and managed together. It is at these assembling markets that most of the transaction takes place. Middlemen, butchers and also traders converge to this market to make the best purchases and value for money. There is considerable variation in the size of these markets and their importance, which is largely determined by the proximity to large cities, and the market demand.

Secondly, the distribution markets are usually found in peri-urban areas close to big cities, with some being found within the cities. Usually, these are also located adjacent to large abattoirs and processing plants. Traders purchase the animals from the assembling markets, bring it this distribution markets, and then sell them to butchers and wholesale meat dealers. This task is often also undertaken by middlemen or commission agents. The transactions in these markets are made to synchronize with the operations of the abattoirs and processing plants.

Thirdly there are the weekly markets. These are very common in the peri-urban and urban areas of most large cities throughout Asia. In addition to the sale of goats and sheep, large ruminants and camels are also sold in these markets. They are held in open areas, and receive the minimum of management in terms of feed and water supply. The animals are held here until the transaction is over, failing which they either return to the village are or are disposed of at very low prices. These weekly markets are usually controlled by the municipalities, who lease the land to interested parties, who in turn impose and collect an entrance fee depending of the species of animals and the numbers involved. Village markets are held on specific days during the week and usually function all day.

Successful marketing and disposal of the goats is largely dependent on negotiating skills and experience of the farmers. It starts with gauging the value of the animals by an arbitrary subjective physical examination. Live weight, sex, age and general body condition of the animals. The traders and middlemen provide a judgment usually in their favor. Price negotiations eventually leads to price fixing, and the traders collect and send the animals to the abattoirs.

Market function is affected by season and weather conditions. Rainy weather limits the transportation of animals, which I turn affects the delivery of animals. The number of animals delivered on a god day is variable, and depends on the location and market demand. In general, the delivery of $600-1000$ animals is normal, with $1000-4000$ animals with the larger markets. In some parts of Andhra Pradesh state in India, a few markets have recorded the delivery of up to 7000 animals in a single day. 


\begin{tabular}{|l|l|}
\hline \multicolumn{1}{|c|}{ Products } & \multicolumn{1}{|c|}{ Services } \\
\hline $\begin{array}{l}\text { Meat (raw, cooked, blood, soup, goat meat } \\
\text { extract - " Zeungtang “ in Korea) }\end{array}$ & $\begin{array}{l}\text { Cash income and investment } \\
\text { Security and insurance }\end{array}$ \\
\hline Milk (fresh, sour, yoghurt, butter, cheeses) & Prestige in ownership \\
\hline $\begin{array}{l}\text { Skins (clothes, shoes, water/grain containers, tents, handicraft, shadow play in } \\
\text { Indonesia, thongs etc.) }\end{array}$ & $\begin{array}{l}\text { Gifts and loans } \\
\text { Religious rituals e.g. Sacrificial slaughter } \\
\text { Human nutrition - characteristics of meat and milk }\end{array}$ \\
\hline Hair (cashmere, mohair, garments, coarse hair rugs, tents, ropes, wigs, fish lures) & $\begin{array}{l}\text { Pack transport and draught power } \\
\text { Draught power }\end{array}$ \\
\hline Horns & Medicine \\
\hline Bones (handicraft) & Control of bush encroachment \\
\hline Manure and urine (crops, fish) & Guiding sheep \\
\hline
\end{tabular}

Table 8: Goat products and services in Asia [12].

Not all farmers are keen to use these marketing outlets for several reasons. These include the belief that the bargaining power is greater when the animals are on their farm, inadequate time to herd the animals to the assembling markets, fear of being cheated, no sales, and fear of contacting diseases should the animals have to return to the farm when they are unsold. Such happenings are more exception rather than the normal.

\section{Rural Markets}

Rural markets are very common in Asia, and are a very important component of the marketing systems. These centres have the supreme advantage of overcoming current constraints in the marketing of goats and sheep. In India for example, the constraints involve the transportation of animals over long distances and several days (2-4 days), dubious quality of vehicles, variable weight loss in transit, interference of unscrupulous middlemen, very poor quality of old abattoirs, loss of animals from mismanagement such as dehydration, and contamination of meat for sale. Earlier studies ahead of the implementation of the project gave the following findings: 9-10\% shrinkage in the live weight of animals during transportation, and farmer's only get $40-60 \%$ revenue from the slaughter of goats. Up to 84 hours of travel is involved during which time the animals are starved.

Major characteristics of rural markets are as follows:-

- Serve as a centre for linking farmers with the municipality and government officials

- Benefits to farmers include reduced transportation and transaction costs

- Reduced transportation over short distances means lesser losses of animal

- Lower cost of meat for the consumers

- Increased bargaining power for farmers and increased income

- Exploitation by middlemen and traders is reduced and removed

- Serve as a center for information exchange, technology delivery empowerment, training and government intervention, and

- Promotes village and rural cohesion.

\section{Constraints to marketing}

Current constraints to the marketing of goats by farmers are as follows:-

Low underestimated prices

Inadequate marketing and bargaining skills

Dependence on village agents

Unscrupulous middlemen and retailers

Underestimation of live weight during sales

Under age sale of animals

Forced feeding of animals with water before sale, and

Depletion of breeding animals and genetic erosion.

The collective losses from these factors are considerable. It has been estimated that the extent of marketing loss to farmer is about $40-45 \%$ [32]. Apart from providing an economic advantage to the owners and traders of goats, these rural markets also enable a very useful socioeconomic function, such as cohesiveness.

The presence of rural markets overcomes many of these constraints, and is especially important to resource-poor and illiterate rural communities and their households. These markets are also convenient for the sale of smaller numbers or fewer live animals for slaughter in the urban abattoirs. With goats for example, this is particularly suitable for small farmers with smaller numbers of animals (3-15 heads). In addition, the markets also provide a venue for small farmers to meet, exchange of ideas, benefit from potential improvements, informal training, and perhaps even the promotion of solidarity and a unified voice. The presence of non-government organizations (NGOs) in the vicinity also benefit from the use of these centers to discuss technology delivery and the promotion of empowerment.

\section{Procedures in the sale of goats and sheep}

- Goats and sheep are sold in one of three ways: per head, per pair or per group. Of these the per pair method is the most common. 
- The commission agent is responsible for settling the deals on any related problems.

- The major determinant of price for the animal is anticipated yield of meat in addition to the sex, age, live weight and body condition of the animal

- Anticipated meat yield is ascertained by the buyer by physical examination of the loin area, the thighs and back areas. Very often crude measurements of the live weight are made

- The animals sold are then transported by trucks that hold 50-100 animals to various abattoirs.

- Quite often farmers share the cost of transportation of the animals sold

- It has also been observed that distance of the farm from the rural market does make a difference... Farmers are usually at a disadvantage, and the bargaining power and sale prices decreases with increasing distance of the farms from the village markets, and

- Occasionally unsold goats and sheep remain for one reason or other. These return to the farm, and are brought back for sale at the next weekly market day.

\section{Development of a Rural Meat Production and Processing Centre (RMPPC) and CLRI}

Most national programs concerned with goats and sheep are involved with post-production centers, as a consequence of which there is poor understanding of value chains prevail, which in turn does not enhance the livelihoods of poor small farmers and the landless, and the productivity of animals. The Central Leather Research Institute (CLRI) also studied the value of setting up a Rural Meat Production and Processing Centre (RMPPC) in Chennur, near Gudur in the Nellore district, India. This task was preceded by detailed surveys of small ruminant farms in several states, socio-economic status of farmers, local government units, traders, and transport agents. The Centre enabled the direct purchase of goats and sheep for slaughter and packaging the meat for sale in urban areas and as far Chennai. The response to this innovation was good. The potential replication of the model elsewhere has the added possibility of promoting greater interest for the owners and producers of goats and sheep to increase the number of animals available for slaughter, as well as the processing of skins, and the development of tanneries [32].

In order to provide good links between rural and urban markets, appropriate infrastructural and communication facilities must be in place, in addition to collection and processing centres. Without improved marketing transport systems, the prevailing systems constitute major constraints to the sale of animals and products from small farms. Because of the greater market demand for animal products in urban areas, transport facilities become essential. Urban markets are the outlets for exports, and promote international trade.

Some idea of the prevailing situation pertaining to the meat trade is given in Figure 2, specific to Pakistan. Note that the value chain for meats involves several steps. Also to be noted is the reference to village markets which are very beneficial to small farms and the landless and cater of small number of animals from traditional farming systems and where there is no processing. The larger abattoirs cope with larger animal numbers from commercial farms in peri-urban and urban areas, and meat processing is also associated with securing the use of skins and also of also of offal's (head, legs and intestines) all of which have economic value.

\section{Transportation}

An important component of the production to consumption systems process, concerns transportation of the animals. It is one of the most stressful sectors and is often associated with significant loss of body weight, considerable bruising, and also mortality. The problems of injuries are also exacerbated by a combination of climatic. nutritional and behavioral factors.

Stresses also produce a number of physiological changes in the meat, one of which is muscle glycogen content. Changes in rapid glycolysis and $\mathrm{pH}$ denature muscle proteins, which result in soft pale looking meat which is unacceptable to consumers (Figures 2 and 3).

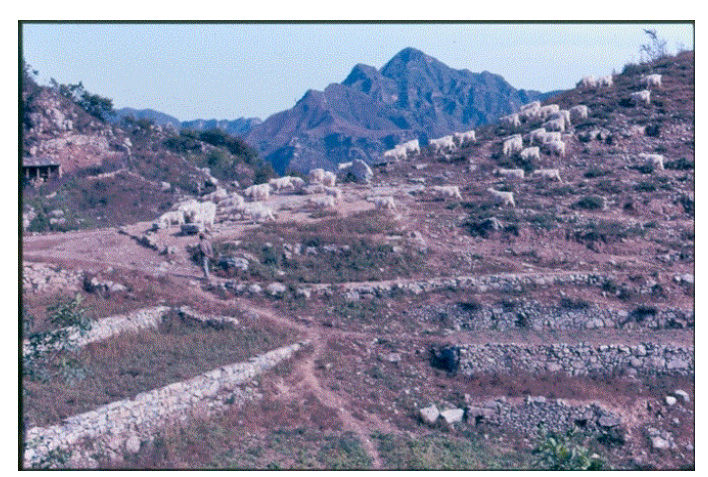

Figure 2: Liaoning cashmere goats grazing in the high hills in Liaoning province, China. Note the rangeland environment and very difficult rainfed biophysical environment (C.Devendra).

Transportation from the farm to the abattoir is usually done in lorries of different sizes and condition. Within the city and shorter distances, bullock carts, trishaws, bicycles and even taxis are used. Invariably overcrowding is come in the process. A typical journey which is common is travelling $600-1000 \mathrm{~km}$ in 24 hours. During this period, the animals are not given any water or feed, until they reach the delivery point. Some losses of animals, especially those in poor condition are to be expected. Once the animals are delivered to the market scene, their sale is confirmed for slaughter only after they given feeds and water.

\section{Value Chains for Goat Meat Production and Consumption}

Value chains provide an important means to understand the various elements and stages from production to consumption, including the many services involved. They include inter alia resource inputs, supplies, production, handling, transportation and processing. More particularly, the assessment enables identification of those factors that need to be improved to benefit small farmers. 


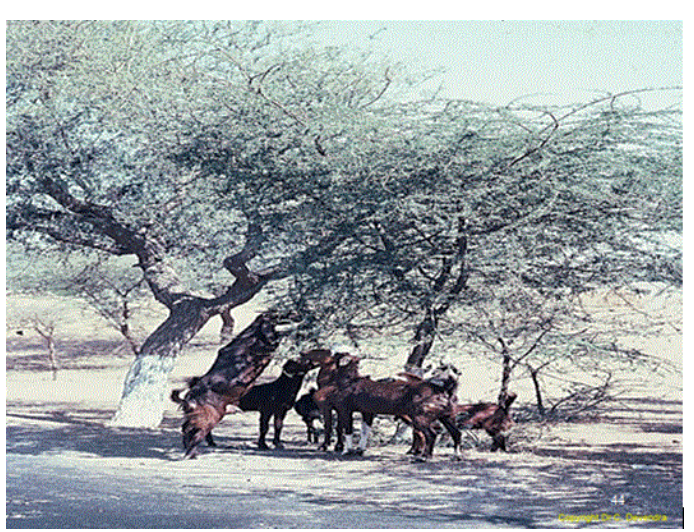

Figure 3: Jamnapari goats browsing on Acasia trees in arid AEZ in western Rajasthan. With little or no herbage growth, tree leaves provide a major source of dietary nutrients for production (C.Devendra).

Value chains are essential to support and enable the various stages from production to consumption, including the many services, all of which have evolved in tandem with local circumstances, culture and tradition. Unfortunately, there exists a diversity of supply and value chains, ranging from small links in individual small farmers who are dependent on unscrupulous middlemen, to more advanced agribusiness systems. Nevertheless, understanding the nature and operation of value chains is important and, include inter alia definition of type of product, resource inputs, supplies, production systems, handling, transportation and processing, type of markets and marketing systems. The market chain involves rural, peril-urban, urban and international markets, and a major challenge lies in ways to link small farmers with these markets, marketing systems and services (Figures 4 and 5).

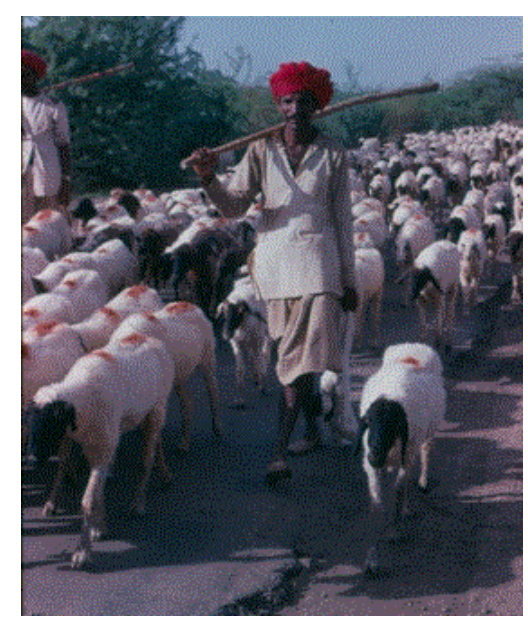

Figure 4: Shepherd from the Mahabubnagar district in Andhra Pradesh, India, migrating with his flock of sheep and goats and his family to the canal irrigated areas near Srisailam during the summer (C.Devendra).
Small farmers have major problems coping with a range of difficulties in the face of the complexity and general inefficiency of the prevailing marketing and value chains. Foremost among these is access to marketing and to the marketing chain. At present, inadequate access to market outlets and weak marketing arrangements represent a major constraint to the production to consumption systems and to the owners and producers of sheep and goats. As a consequence, small farmers are often denied compelling opportunities and economic benefits.

While the traditional pathway in industrialized countries is only concerned with production to consumption systems, the concept of rural markets is very much an Asian entity, and has evolved naturally in direct response to several constraints and the practical needs of dealing with very diverse and haphazard marketing systems.

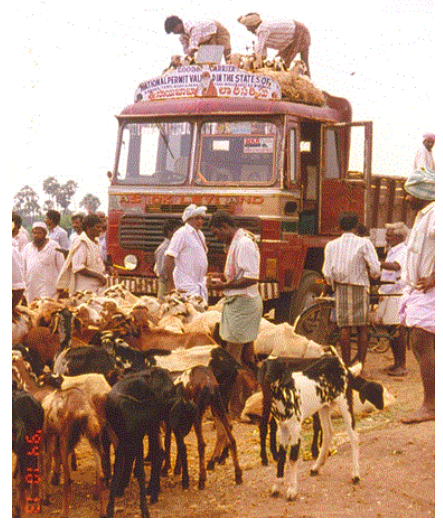

Figure 5: A typical market scene in India. goats being loaded with animals on top of the truck for transportation in Andhra Pradesh, India. The farmer (in green) and the trader (in white) have just completed price negotiations (C.Devendra).

These systems are especially important to rural communities and their households, and are also used for the sale of live animals for slaughter in the urban areas. In order to provide good links between rural and urban markets, appropriate infrastructural and communication facilities must be in place, in addition to collection and processing centres. Without improved marketing and transport systems, the prevailing systems constitute major constraints to the sale of animals and products from small farms, detached from value chains. Because of the greater market demand for animal products in urban areas, transport facilities become essential. Urban markets are the outlets for exports, and promote international trade (Figure 6).

Commitment by institutions and organizational improvements is critical in improving value chain performance. In this context, joint partnerships particularly with the private sector can also be very useful to sustain and improve value chains. It is also relevant to note that an additional feature that can be beneficially introduced is a business approach in which key goals are identified and monitored through quantitative performance targets $[33,34]$. The capacity and ability to implement this business approach will be critical to determine success [35]. In India, The empirical evidence from dairy development suggests benefits from participation in value chains [36]. 


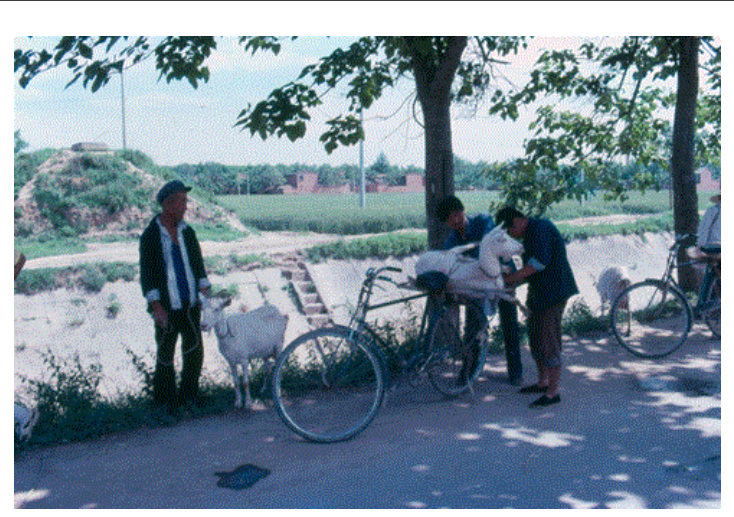

Figure 6: The photo shows a small farmer having bought a goat, organizing transportation in his bicycle to return his farm in a Beijing suburb, China (C.Devendra).

\section{Post-Production Systems}

Post-production systems are part of the production process, and are just as important in the generation of income in the totality of goat production systems. They are an integral component of the food chain, and recognition of this chain ensures promotion of the interdependence between the production resources, farmers, traders, processors and consumers. Production, products and by-products need to be seen in the context of production to consumption systems in the food chain. Recognition of this chain ensures understanding and promotion of the inter-dependence between the production resources, producers, processors and the consumers.

The production to consumption concept that links the producer, distributor and consumer has two development impacts. Firstly, it will link and encourage the location of production, slaughter and distribution, marketing and product flows. Secondly, it will also significantly enhance the linkages between rural and peri-urban areas which are most essential in the marketing of the produce. The strength of these linkages, improved marketing systems, and resolution of the major constraints has the potential to promote rural growth. He chain is concerned not only with the edible products of meat and milk, but also with other products such as fiber and also by-products like skins, leather and offal's.

The components of post-production systems are:-

- Collection -- methods of collection, including transportation, are important since these affect slaughter weight and quality of the meat

- Handling -- includes mode, duration and management during transportation

- Marketing -- distinct outlets, organisation and their capacity, sale and bargaining skills

- Slaughter facilities -- size, adequacy, hygiene, location, and methods used to salvage by-products and waste disposal

- Consumer requirements -- nature, extent, quality and characteristics. These need to be addressed in relation to changing trends (preferences, traditions, incomes and purchasing power) and affordability.
Farmers will generally not undertake production of the animals if there is no access to market for their produce, marketing channels for goat products, belief and confidence in fair value for their animals. Conversely, they will be quick to respond to a market demand when they see distinct opportunities for selling the produce to generate income.

- Concurrently, there is also an urgent need for more information on several aspects of the diversity of markets inter alia as follows:-

- Rural markets, their specific characteristics and benefits to farmers

- Marketing infrastructure and facilities

- Market channels and outlets in the value chains

- Buyer preferences for live animals and their meats

- Methods of transportation and management of animals

- Trends in dietary changes and preferences

- Major market players ( categories, functions and methods used)

- Methods used to purchase the animals and also price fixing

- Government intervention and institutional support

- Standards of hygiene and methods used to process high quality meats

- Policy to support value chains and organized transportation

- Role of the private sector, and

- Policy framework to define improved supply and value chains

\section{Types of Products and End Uses}

The slaughter of goats results in a variety of products, by-products, uses, and more importantly, value addition to these. These will vary from country to country, but the fact remains that there is extensive use of the materials, and in various ways. It is for this reason that the total saleable value of a goat carcass is nearer $100 \%$ compared to sheep. Goat meat can be used raw or cooked or as soup. In Muslim countries such as Indonesia and Malaysia, the bones of the goat carcass including the feet and head are boiled to make soup which is widely consumed. In Korea, an extract from goat meat called "Zeungtang" is produced which has medicinal properties, and is also marketed overseas (Table 8).

Post-production aspects are not given the attention they deserve; including commercial potential, ad much more can be done. Of the countries in Asia, India is probably the lead country where there is considerable knowledge on post-production aspects as well as commercialization in both goats and sheep. At least eight slaughter products are common : skins, blood, intestines, liver, bile, rumen ingesta, tannery hair and wool, and skin trimmings and flashings. It is clear that a range of end products are involved, as also their uses. Many industries are involved, and contribute to the value addition. For example, with skins the latter is 2-5 times, blood 2-6 times, liver 8-10 times, and tannery hair and wool 4-5 times. Of these, the value addition up to 20 times for skins in European markets is phenomenal, as a result of which goat skins in India are no longer referred to as a by-product, but a core product.

\section{Economic Benefits and Social Factors}

To further emphasise the value of instituting improvements in the supply and value chains, and also concurrently demonstrate potential economic impacts, it is now appropriate to cite examples that draw attention to these facts, and concurrently demonstrate what can be achieved. 
In this section attention is drawn to economic analyses and social factors that are associated with extensive goat production systems. This approach is consistent with the emphasis and focus on extensive systems in this chapter. The fact remains that there is a paucity of economic analyses and reported results on this subject. Nevertheless the few reports below serve to reflect the economic significance of extensive goat and sheep production systems. It is important to stress that because extensive systems are characterized by very minimal production inputs, the economic benefits and returns are likely to be highest in these systems. Four field studies are cited: three from India and for comparative reasons one from Cyprus.

\section{India: comparative income from goats and sheep in migratory and stationary systems}

One of the earliest studies was the comparative income from goats and sheep was studied under both a migratory and a stationary system in Himachal Pradesh. The income and return on capital from goats exceeded that from sheep under both systems. Return on capital in both situations exceeded that obtained in the temperate zones [37]

\section{India: Documentation of practices and approaches concerning market prospects, and opportunities for the access of small ruminant owners to more remunerative markets}

India has the largest population of goats and sheep in Asia, which in 2010 were 588 and 594 million respectively. The study assessments were undertaken over a six month period, and involved detailed analyses through the use of questionnaires, site visits, and discussions with colleagues on the telephone. The site visits included farms and shepherds, district level markets, terminal markets, manufacturing units and officials of the local municipality.

About $70 \%$ of national the goat populations were found to be distributed across several types of AEZs, in the states of West Bengal, Rajasthan, Uttar Pradesh, Maharashtra, Bihar, Tamil Nadu and Madhya Pradesh. These same states also boast of a long history of breeding and the management of goats.

Sheep were concentrated mostly in the semi-arid and arid AEZs, and in the western region of the Deccan plateau, western Himalayas, Andhra Pradesh, Rajasthan, Karnataka, Tamil Nadu, and Jammu and Kashmir. Invariably and traditionally, the goats and sheep are reread and managed together by farmers in extensive systems, with very little inputs from them. The sum total of management constitutes some attention to housing and deworming if they can find a government veterinary officer who can give the drug for free. It is especially significant to note that about $70 \%$ of the goat and sheep populations were reared by small farmers [38]. In order to have a clear picture of the value chain for meat and meat products, the study also included the meat, leather industry, and wool industries to understand implications for policy and the definition of suitable recommendations.

Village markets were important and found to be the most accessible to breeders and owners, but were the most underdeveloped, unregulated and haphazard. Nevertheless, these village markets were the most used for negotiating prices for sale and the like. Farmers are usually at a disadvantage, and the bargaining power and sale prices decreases with increasing distance of the farms from the village markets. Commission agents are central players in transactions in the meat trade and industry. No processing is undertaken in the village markets.

Supplies of animals for the slaughter houses come mainly from Madhya Pradesh, and these are evidently seasonal in the supply as follows:-

- December-January: From Uttar Pradesh, and the Malwa region of Madhya Pradesh

- March-April: From Rajasthan

- April-June: From Rajasthan

- July - August: From the Terengganu region of Andhra Pradesh

- September-November: From coastal Andhra and Rayalseema region of the state.

Some calculated range of incomes earned by different sources in the study is as follows:-

- Income for shepherds: Rs 100-150

- Annual return/animal: Rs 1100

- Average annual income of an owner or shepherd is Rs 50,000 100,000

- Annual income of village butcher: Rs 168,000

- Annual income of town butcher: Rs 200,000

- Trader in terminal markets: Rs One million /annum

- Urban retailers income: Rs 700,000

- Agents income: $1-4 \%$ of the selling price of the animal

- For a flock size of 10 bucks the family income is: Rs $25,000-35,000$ over 10 months

- Cost of procurement of skins, salting and storage is about Rs 3-8 per piece.

\section{(NB: I US \$ =54 Rs approximately)}

To highlight the economic benefits, and the range on incomes earned, two examples of calculations are illustrated that were based on field data. Tables 9 and 10 are given below, summarized from the extensive studies of Mehta et al. [38]. Table 9 reflects a case study of an experienced farmer engaged in lamb fattening in Karnataka, India. After several years of generated income, he now has a building of his own. Table 10 presents a broad calculation of income earned by a butcher in Rajasthan. The income is much lower as he has to gauge the demand for meat and then buy his animal numbers accordingly.

Both studies do emphasize however, that there is money to be made even in low input systems, which with intensification is likely to generate higher even higher returns, particularly improved livelihoods of the poor.

\section{Folding}

A husbandry issue that has got economic significance, and is quite common in India is the practice of folding. The migrating flocks of goats and sheep are often used overnight to fertilize crop land, and crop farmers pay relatively high prices or give cereals in return for their service in practices called folding. In northern India, this means for example, 2000-3000 goats and sheep folded on 0.2 ha of land costing 1 US\$ per 100 animals per night or $60-80 \mathrm{~kg}$ of grain in return [39]. 
Page 18 of 21

\begin{tabular}{|l|l|}
\hline \multicolumn{1}{|c|}{ Costs and amount (Rs) } & \multicolumn{1}{c|}{ Initial costs } \\
\hline Construction of bamboo shed & 30,000 \\
\hline Cost of steel and 2 concrete troughs & 10,000 \\
\hline Cost of 126 lambs at 2000 each & 252,000 \\
\hline Insurance & 4,000 \\
\hline Miscellaneous costs & 5,000 \\
\hline Feed cost (6.2 Rs /animal/for 146 goats stall-fed at & 126.000 \\
\hline Vaccination and deworming & 3,780 \\
\hline Total cost & 430,780 \\
\hline Benefits (Rs) & Initial costs \\
\hline Sale of lambs at 4.500 Rs/animal & 495,000 \\
\hline Sale of manure 4.0 tons at 5,000 Rs/ton & 20,000 \\
\hline Insurance claims recovered (16 lambs at 1800 Rs each) & 28,800 \\
\hline Total & 543,800 \\
\hline
\end{tabular}

than sheep, and that the top $25 \%$ of the herds on a production/female basis had profitability double that of the bottom $25 \%$.

\section{Potential Markets}

Assessment of niche markets for goat meat and other products, aided by trade opportunities and globalization have indicated that there was a very large and emerging market for innovative products from goats. Commercialization was an obvious means to link with these opportunities. Large markets exist in the Middle East region with concurrent potentially economic benefits. Likewise in the Caribbean Commonwealth

(CARICOM) should take cognisance of the opportunity for rapidly changing trade and marketing of goat meat in the U.S.A. [10]. Some related features are of the demand trends and potential opportunities are worthy of note:-

- The number of meat goat farms increased by $18 \%$

- The number of meat goats increased more than $57 \%$ between 1997-2002

- The number of farms selling meat goats increased by $48 \%$ with over a $108 \%$ increase in meat goat sales.

Table 9: Economics of lamb fattening; The estimated profit per lamb is 1,300 Rs over 6 months. In a flock, $13 \%$ mortality is envisaged ${ }^{*}$

\begin{tabular}{|l|l|}
\hline Particulars and amount ( Rs) & 2.300 \\
\hline Cost. ofa Sirohi buck & $12 \mathrm{Kg}$ \\
\hline Potential meat output & 2,640 \\
\hline Revenue from the sale of meat at 220 Rs/Kg & 450 \\
\hline Revenue from offals ( head, legs and intestine) & 50 \\
\hline Returns from the sale of skin & \\
\hline
\end{tabular}

Table 10: Economic analyses of rearing a buck; Net profit: 840 Rs per buck; The revenue earned from a buck is $840 \mathrm{Rs} / \mathrm{buck}^{*}$.

*The data for Tables 9 and 10 are reported by Mehta (2011), and have been adapted to show distinct economic benefits from owning or rearing small ruminants in different ways, but in an environment of low inputs and pro-poor orientation. The study also reported the approaches and methods of husbandry used by these small farmers and the landless.

Similarly, in the rice growing countries in South East Asia and East Asia, landless farmers produce ducks by feeding after feeding on fallen grains and also weeds after the rice harvest and the sell them to the market. In Turkey, following browsing by day, goats are often kept in paddocks and corrals at night, and their droppings are carefully collected and sold by the bag to local farmers [26,39-41].

\section{Cyprus: Assessment of production and profitability of dairy goats and sheep}

In Cyprus, surveys were conducted on the production and profitability of goat and sheep herds producing milk and surplus stock [42]. They showed that smaller herds tended to have a higher milk production per female and a higher lambing/kidding percentage than larger herds. Also, the profitability of goats was considerably higher According to the 2007 USDA-NASS sample data, the meat goat population increased by $29 \%$ over the 2002 USDA Census.

- The United States was a net exporter of goat meat up until 1990, but exports ceased due to increased domestic demand after 1991. This shift is an indication of increased interest in goat meat consumption nationally. In 2007, the U.S. imported $10,166 \mathrm{mt}$, valued at US\$ 37 million - an increase of $146 \%$ from $6,982 \mathrm{mt}$ in 2002; its price per $\mathrm{kg}$ was up 173\% from \$2.11 in 2002.

These studies together indicate that in the developing countries, traditional systems are highly efficient in economic terms. This is due to low input systems where very low levels of resources, and low cash inputs are used. Additionally, the relatively high reproductive rate of some breeds of tropical goats which regularly give over $120 \%$ per breeding female in small farm systems could also have influenced the level of efficiency. Much more information will be useful to understand traditional systems and their many virtues.

In considering export trade, the first priority of course is to maximise domestic production to meet national needs, with available predictable technologies based on increasing intensification and specialization. Beyond this, the opportunities for participation in large scale goat meat markets within- and between-regions are enormous, notwithstanding addressing issues of logistics and trans-boundary diseases. A broad view of the opportunities reflected below, backed by policy and wider engagement, can pave the way for a vibrant export trade (Table 11).

\section{Implications for $\mathrm{R}$ and $\mathrm{D}$}

The subject of value chains is relatively new, and the paucity of knowledge on this topic emphasizes the importance of training and empowerment. With systems of production becoming increasingly intensive, in this case from the very extensive to progressive intensification, competition for the use of scarce resources on-farm, more sophisticated consumer preferences, the need for good hygiene, and understanding the diversity of these systems is essential. 


\begin{tabular}{|l|l|}
\hline \multicolumn{1}{|c|}{ Region } & \multicolumn{1}{c|}{ Areas with export potential } \\
\hline Australia and New Zealand & Middle East region: South East Asia \\
\hline South East Asia & Middle East region \\
\hline South Asia & Middle East region \\
\hline North Africa & Middle East region \\
\hline West and East Africa & North Africa \\
\hline South America & Central America \\
\hline Caribbean & Southern USA \\
\hline
\end{tabular}

Table 11: Region -wise target areas with export potential

There is no doubt that well formulated and targeted $\mathrm{R}$ and $\mathrm{D}$ programmers can result in significant outputs in productivity. Affirmative action is necessary to resolve prevailing deterrent factors such as waning agriculture, constraints to decreasing agricultural productivity, the awesome dilemma of inadequacy of food supplies to meet human requirements - current and projected, inadequate application of appropriate technology and poor delivery systems to farmers. Increasing productivity is the immediate objective, and this is to ensure the application of technology options from research that impacts on development in which sustainable intensification is inevitable, In this context, efficient use of the feed resources in several potentially important productivity-enhancing technology options merit urgent application [16], and followed through to demonstrate a successful project. Please see the definitions given below for successful and failed projects in the foot note.

\section{Foot Note}

X Definition of successful and failed projects [16].

$\mathrm{X}$ In order to provide good understanding of the success or failure of individual projects, it is necessary to define these elements to keep the issues in perspective. We provide the following definitions:-

- Successful - projects that are able to meet the objectives, contribute especially to food security and increased income, and show evidence of acceptance, adoption and replication by farmers. Additionally, the projects also demonstrate potential to contribute to self-reliance, stable farm households, and sustainable development. Successful projects also recognize systems perspectives, are usually associated with effective participatory research-extension-farm linkage, and are often associated with the significant contribution of women to animal production. These issues also have to be sustainable or be able to be modified as resource availability and costs escalate in the future.

- Failure - projects that are associated with poor understanding and unsuccessful realization of the objectives, inadequate technical know-how, are weak, do not have participatory application, have increased costs, do not fit into a time frame, and do not mesh with the farm calendar. The beneficial aspects in socio-economic terms are unrealized and not appreciated. Consequently, the projects do not produce tangible impacts, are seldom considered for wider scaling up, testing and adoption on farm. The poor results impede the incorporation of the technology to enhance wider development of sustainable production systems. X
Associated with above, there is a critical need to have more information and understanding of the different centers of goat meat production and their value. Rural production and processing centers are different and unique, very much part of improved value chains in Asia, and provide socio-economic benefits. Well formulated and targeted $\mathrm{R}$ and $\mathrm{D}$ programs, including the experience of the Green revolution, can result in significant outputs in productivity. Affirmative action is necessary to resolve waning agriculture, constraints to decreasing agricultural productivity, the awesome dilemma of inadequacy of food supplies to meet human requirements - current and projected, inadequate application of appropriate technology, and patterns of marketing and marketing systems, improved livelihoods and increased self-reliance.

\section{Development and the Policy Framework}

Currently, systems perspectives, systems approaches and interdisciplinarity are minimal despite the dominant emphasis on mixed farming in Asia. Research on crop-animal systems is seldom integrated. With rare exceptions, very few institutions recognize the importance of training in agricultural systems research. The complex and interrelated systems-based problems in crop-animal systems are currently not addressed in holistic terms, and this tendency explains why improved productivity from animals in small farm systems is slow to be realized. The same reasons also apply for the general neglect of the rainfed areas, the inadequate productivity from small farm systems therein, and the contribution from animals. The systems approach requires multi-and interdisciplinary interpretation of the different components of the system and biophysical environment, identified through detailed analyses of the constraints, needs and opportunities. Ways and means need to be found to assess all possible ways to increase food production, and trends in the supply situation.

For development to make impact, a supportive policy framework is most important identify ways to increase agricultural production, policies for improved production, trade, distribution and wastage. The development of efficient value chains and promotes the potential future contribution of goats. These include (i) policy through advocacy (ie education and empowerment, (ii) gender, (iii) investment in $\mathrm{R}$ and $\mathrm{D}$, and (iv) through law (i.e. microcredit's and NGO participation). These aspects have been discussed [43, 44].

The following areas merit priority attention inter alia:-

1. Policy support and institutional commitment are necessary

2. Goats provide a unique and multifunctional niche in small farm systems and especially rained environments

3. Increased production will need better use of the available breeds and commercially-oriented production systems

4. Comparative studies on the socio-economic contribution of goats in sheep in extensive systems, impacts and lifetime performance

5. Identify ways to increase goat performance and policies to improve production

6. Efficient management of the natural resources, including innovation and self-reliance

7. Value addition in the products from goats and sheep, and

8. Understand markets and all aspects of marketing systems

9. Owners and producers of goats must think more nationally and regionally 
10. Need for awareness and understanding of the concept of production- to -consumption systems, the various components and their functions, and

11. Increased resource use (Figure 7).

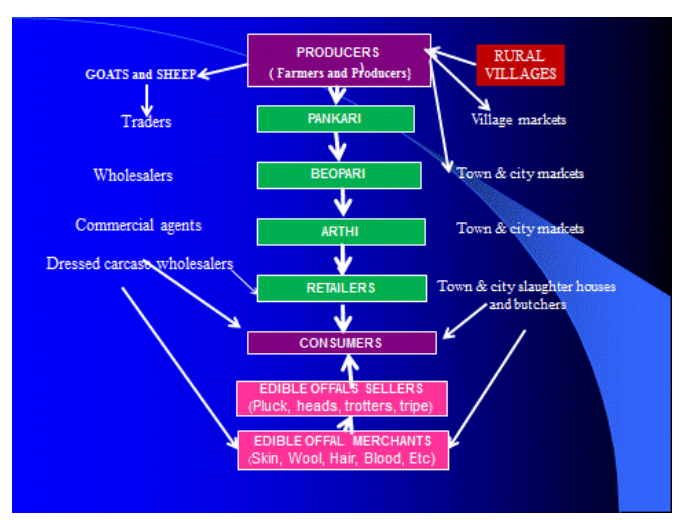

Figure 7: Marketing channels for ruminant meats in Pakistan [45]

\section{Conclusions}

Agriculture must continue to:-

- Produce and provide access to reasonably priced food

- Ensure the integrity of the natural resources that support agriculture, and

- Enhance environmental sustainability that agriculture depends on.

The rapid growth of the livestock sub-sector, and the huge demand for meat and milk require efficient NRM and production systems need to increase these supplies from the totality of the ruminant resources. For the small farmers and the landless, the opportunities for improving goat production are constrained by ignorance, illiteracy and financial negotiating skills. Encouraging their participation, regular training and empowerment can make a significant contribution to improved animal production, including demonstrable transformation of the poorest and marginalized, as agents of change. Increasing intensification and effective management can further boost the supply of animal proteins with supportive policies to secure and sustained food supplies for the poor in sustainable animal-agriculture systems in the future $[2,43]$.

Value chains can greatly enhance well considered and problemsolving livestock development programs which can provide many benefits to resource-poor farmers throughout the developing world. In response to the vigorous demand for meat, shifts to intensification and higher levels of production are feasible. Concurrently, the shortage of arable land will drive development attention to the LFAs, where the large concentrations of mainly goats but also sheep; these can be used as an entry point for the development of the LFAs [19]. Complex issues such as resource allocation, value chains, trade, marketing and climate change will need interdisciplinary R and D [25, 46]. These tasks are massive but program commitment, multinational engagement and strategic investments can demonstrate singularly beneficial impacts that can significantly improve the quality of life for millions of the poorest of the poor. For Asia, the aspiration is that of a continent which is a model of efficiency, self-reliant in the environmentally sustainable management of the natural resources, and is free from hunger.

The focused agenda provides a shared vision for many commonalities in agricultural development in Asia and Africa. Small ruminant production in particular in both continents provides very good opportunities for collaborative efforts. Strong links already exist in formal agricultural education at the college and university levels, but these can be substantially expanded to other innovative partnerships that recognise similar problems and their resolution of direct benefit to West Africa and also for Asia [47, 48].

\section{Acknowledgements}

The author acknowledges with deep gratitude the long hours of extensive discussions and comments from my able colleagues Dr. K. Seshagiri Rao, Dr. A. Subbarama Naidu and Mr. D. Chandramouli, all of whom were formerly in the Economics Division, CLRI, and Chennai, India. These enriched the paper. My thanks are also due to Professor N. Krishna, former Associate Dean and Head of the Department of Animal Nutrition, College of Veterinary Science in Rajendranagar, Hyderabad, India.

\section{References}

1. Otte J, Costales A, Dijkman J, Pica-Ciamara U, Robinson T, Ahuja V, et al. (2012) Livestock sector development for poverty reduction: an economic and policy perspective. FAO, Italy.

2. Devendra C, Chantalakhana C (2002) Animals, poor people and food insecurity: opportunities for improved livelihoods through efficient natural resource management. Outlk.on Agric 31: 161-175.

3. Devendra C (2012a) Multifunctional relevance and contribution of dairy goats to food and nutrition security. In: Proc. First Asian Dairy Goat Conf. Kuala Lumpur, Malaysia: 1-6

4. Devendra C, Liang JB (2012) Conference summary of dairy goats in Asia: Current status, multifunctional contribution to food security and potential improvements. Small Ruminant Res 108: 1-11.

5. Astuti DA (2014) Country Report Indonesia, Asian-Austral. Dairy Goat Network, :http//aadgn.upm.edu.my/aadgn/pp.33-42

6. Liang JB, Devendra C (2014) Expanding the contribution of dairy goats in efficient and sustainable production systems. Anim Prod Sci 54: 11981203

7. Devendra C, Coop IE (1982) Ecology and distribution. In: Sheep and Goat producton. (Ed.I.E.Coop), World Animal Science, Elsevier Scientific Publishing Company, Amsterdam, the Netherlands:pp. 1-14.

8. Central Leather Research Institute (CLRI) (2005) Report on Raw hides and skins markets. Central Leather Research Institute, Chennai, India, 309pp.,

9. Devendra C (1987) Herbivores in the arid and the wet tropics. In: The Nutrition of Herbivores. Proc. of the 2nd Int. Symp. on the Nutrition of Herbivores. Academic Press, New South Wales, Australia:pp. 23-46

10. Devendra C (2013) Investments on Pro-poor Development Projects on Goats: Ensuring Success for Improved Livelihoods. Asian-Austral. J Anim Sci 26: 1-18.

11. FAO (Food and Agriculture Organization) (2013) FAO Stats. (www.faostat.fao.org./site/452/efault.aspx.)

12. Devendra C (2010a) Small farms in Malaysia: revitalising agricultural production, food security and rural food security and rural prosperity. Academy of Sciences Malaysia, Kuala Lumpur, Malaysia 175pp.,

13. Devendra C, Haenlein, GFW (2011) Animals that Produce Dairy Foods. Goat Breeds. Encyclopedia of Dairy Sciences 1: 310-324.

14. Nagayets $O$ (2005) Small farms: current status and key trends. Proc. The future of small farms. International Food Policy Research Institute, Washington, DC, USA, 355 pp. 
15. McDermott J, Staal SJ, Freeman HA, Herrero M, Steeg JA, van de and Casey N (2010) Sustaining intensification of smallholder livestock systems in the tropics. Livestock Sci., 130: 95-109.

16. Devendra C, Leng RA (2011) Feed resources for animals in Asia: Issues, strategies for use, intensification and integration for increased productivity. Asian-Austral. J. Anim. Sci, 24: 303-321.

17. Devendra C, Morton JF, Rischkovsky B (2005) Livestock systems. In: Owen E, Kitalyi A, Jayasuria N, Smith T (Eds) Livestock and wealth creation. Nottingham University Press, Nottingham, UK: pp. 29-52.

18. Thornton PK, Kruska RL, Henninger N, Kristjanson PM, Reid RS, et al. (2002) Mapping poverty and livestock in the developing world. ILRI, Nairobi, Kenya: 118 pp.

19. Devendra C (2014a) The search for efficiency in the management of natural resources. Outlk. on Agric 43: 1-12.

20. Robinson TP, Thornton PK, Franceschini G, Kruska R, Chiozza F, et al. (2011) Global Livestock Production Systems, Rome, International Research Institute (ILRI), Nairobi, Kenya: 152 pp.

21. Spedding CRW (1975) The biology of agricultural systems. Academic Press, London, UK: 132 pp.

22. Devendra C, Thomas D, Jabbar MA, Zerbini E (2000) Improvement of livestock production in crop-animal systems in rainfed agro-ecological zones of South Asia. International Livestock Research Institute (ILRI), Nairobi, Kenya: 108 pp.

23. Carrera C (1971) Tipos de planta consume at Ganado caprino. In xii Inorme de Invstibacion, Estudio, Escuela de agricultury Ganaderia, Insitutotechnologica, y de Estudios Superiore de Monterray.

24. Wilson AD, Mulham WF, Leigh JH (1975) A note on the effects of browsing by feral goats and sheep on a Belah (Casuarina cristata), Rose wood (Heterodendrum oleifolium) woodland. Austral. Rangeland 1: 7-12.

25. Devendran C (2012b) Climate Change Threats and effects: challenges for agriculture and food. Academy of Sciences Malaysia, Kuala Lumpur, Malaysia , 56pp.,

26. Devendra C (2010b) Concluding synthesis and the future for sustainable goat production. Small Ruminant Res 89: 125-139

27. ADB (2009) The Economics of Climate Change in South East Asia: A Regional Review, Asian Development Bank, Manila.

28. Chen CP, Wong HK, Dahalan I (1993) Herbivores and the plantations. Proc.3rd Int. Symp. on the Nutrition of Herbivores (Ed. Ho YW) Penang, Malaysia: 71-81

29. Wong CC, FY Chin FY (1998) Meeting the nutrient requirement of beef cattle from forages in the oil palm plantations. MARDI, Serdang, Selangor, Malaysia, $18 \mathrm{pp}$.

30. Turner HN (1979) Animal production research -small ruminants. Report to MARDI, Serdang, Malaysia, $23 \mathrm{pp}$.

31. Devendra C (2007) Goats: biology, production and development in Asia. Academy of Sciences Malaysia, Kuala Lumpur, Malaysia: 246 pp.

32. Naidu AS, Devendra C, Chandramouli D (2011) Rural meat production and processing meter (RMPCC). J Rural Dev 30: 81-90

33. Clark RA, Timms J, Griffith GR (2008a) The continuous improvement and innovation process. Austral. Farm Business Management J 5: 19-28
34. Clark RA, Timms J, Parnel PF, Griffith GR (2008b) The sustainable improvement and innovation Model. Austral. Farm Business Management J 5: 29-32.

35. Burrow HM, Matjuda E, Strydom P, Nengovhela B Nkhane, Madzivhandila P, Motiang D, Griffith G, Clark R (2008) Developing Profitable Beef Business Systems for Previously Disadvantaged Farmers in South Africa, ACIAR Final Report available online at http:// www.aciar.gov.au/publication/FR: 44.

36. Birthal PS, Joshi PK, Gulati A (2005) Vertical coordination in high value commodities: implications for the smallholders. MTID Discussion Paper No. 85, IFPRI. Washington, DC: USA.

37. Raut KC, Nadkarni UG (1974) Cost of rearing goats under migratory and stationary conditions. Indian J. of Anim. Sci 44: 459-463

38. Biswas S (2010) The Black Bengal goat as a tool in sustainable livelihoods in rural West Bengal. Case study 07-10 of the Program Food Policy for Developing countries. The role of the Government in the global food system, Cornell University, Ithaca, USA.

39. Mehta V (2010) Small ruminant rearing. South Asia, Pro=poor Livestock Policy Programme, NDDB/FAO, New Delhi, India, Annals of Arid Zone $37: 215-232$.

40. Devendra C (2007) Concluding synthesis and the future for sustainable goat production. Small Ruminant Res,89:125-139

41. Devendra C (2012) Rainfed areas and animal agriculture in Asia: the wanting agenda for transforming productivity growth and rural poverty. Asian-Austral. J Anim Sci 25: 122-142.

42. Kolars J (1966) Locational aspects of cultural ecology: the case of the goat in non-western Agriculture. Geographical Rev 56: 577-581.

43. Papas P, Papachristodoulon S (1975) Factors affecting the economics of sheep and goats. Agricultural Economics Report, Department of Agriculture: 29

44. Devendra C (2014b) Gender equity in sustainable animal-agriculture: enhancing empowerment and the contribution of women for improved livelihoods, stable households and rural growth. Proc.2nd Asian-Austral. Dairy Goat Network Conf., Bogor Indonesia,, (Eds)KG Wiryawan, JB Liang, C Devendra, J Takahashi, ER Orskov,DW Astuti) pp. 21-30.

45. Hasnain HU (1985) Sheep and goat breeds of Pakistan. FAO Animal and Production and Health Paper No. 56, Rome, Italy., 135 pp

46. Devendra C, Burns M (1983) Goat Production in the Tropics (Revised Edn.). Tech. Comm. Bureaux of Animal Breeding and Genetics, Commonwealth Agricultural Bureaux, England.

47. Devendra C (2014c) Transforming agricultural education, and technological improvement for enhancing, productivity growth and prosperity in Asia -Shared vision for strengthening Asia-Africa linkages. In: Towards impact and resilience: transformative change in and through agricultural education and training in Sub-Saharan Africa, Cambridge Scholars Press, UK: pp. 90-114.

48. Devendra C, Pezo D (2004) Crop-animal systems in Asia and Latin America: characteristics, trends and emerging challenges. Comparison with West Africa. In: Proc. Int. Conf. on Sustainable crop-livestock production for improved livelihoods and natural resource management. International Livestock Research Institute (ILRI), Nairobi, Kenya. 